\title{
Enhanced Weathering and related element fluxes - a cropland mesocosm approach
}

\author{
Thorben Amann ${ }^{1}$, Jens Hartmann ${ }^{1}$, Eric Struyf ${ }^{2}$, Wagner de Oliveira Garcia ${ }^{1}$, Elke K. Fischer ${ }^{3}$, Ivan Janssens ${ }^{4}$, \\ Patrick Meire $^{2}$, and Jonas Schoelynck ${ }^{2}$ \\ ${ }^{1}$ Institute for Geology, Center for Earth System Research and Sustainability, University of Hamburg, Hamburg, Germany \\ ${ }^{2}$ Department of Biology, Ecosystem Management Research Group, University of Antwerp, \\ Universiteitsplein 1C, 2610 Wilrijk, Belgium \\ ${ }^{3}$ Institute of Geography, Center for Earth System Research and Sustainability, University of Hamburg, Hamburg, Germany \\ ${ }^{4}$ Research Centre of Excellence Global Change Ecology, University of Antwerp, Universiteitsplein 1, 2610 Wilrijk, Belgium
}

Correspondence: Thorben Amann (science@thorbenamann.de)

Received: 6 September 2018 - Discussion started: 2 November 2018

Revised: 11 November 2019 - Accepted: 13 November 2019 - Published: 8 January 2020

\begin{abstract}
The weathering of silicates is a major control on atmospheric $\mathrm{CO}_{2}$ at geologic timescales. It was proposed to enhance this process to actively remove $\mathrm{CO}_{2}$ from the atmosphere. While there are some studies that propose and theoretically analyze the application of rock powder to agricultural land, results from field experiments are still scarce.

In order to evaluate the efficiency and side effects of Enhanced Weathering (EW), a mesocosm experiment was set up and agricultural soil from Belgium was amended with olivine-bearing dunite ground to two different grain sizes, while distinguishing setups with and without crops.

Based on measurements of $\mathrm{Mg}, \mathrm{Si}, \mathrm{pH}$, and DIC, the additional weathering effect of olivine could be confirmed. Calculated weathering rates are up to 3 orders of magnitude lower than found in other studies. The calculated $\mathrm{CO}_{2}$ consumption by weathering based on the outlet water of the mesocosm systems was low with $2.3-4.9 \mathrm{tCO}_{2} \mathrm{~km}^{-2} \mathrm{a}^{-1}$ if compared with previous theoretical estimates. Suspected causes were the removal or dilution of $\mathrm{Mg}$ as a weathering product by processes like adsorption, mineralization, plant uptake, evapotranspiration, and/or preferential flow, not specifically addressed in previous EW experiments for $\mathrm{CO}_{2}$ consumption. The observation that $\mathrm{Mg}$ concentrations in the upper soil layers were about 1 order of magnitude higher than in the outlet water indicates that a careful tracking of weathering indicators like $\mathrm{Mg}$ in the field is essential for a precise estimate of the $\mathrm{CO}_{2}$ consumption potential of EW, specifically under global deployment scenarios with a high diversity
\end{abstract}

of ecosystem settings. Porewater $\mathrm{Mg} / \mathrm{Si}$ molar ratios suggest that dissolved $\mathrm{Si}$ is reprecipitating, forming a cation-depleted Si layer on the reactive mineral surface of freshly ground rocks.

The release of potentially harmful trace elements is an acknowledged side effect of EW. Primarily Ni and $\mathrm{Cr}$ are elevated in the soil solution, while Ni concentrations exceed the limits of drinking water quality. The use of olivine, rich in $\mathrm{Ni}$ and $\mathrm{Cr}$, is not recommended, and alternative rock sources are suggested for the application.

\section{Introduction}

The application of rock powder on agricultural soils has long been used to improve soil properties to achieve a productivity increase (De Villiers, 1961; Kronberg, 1977; Leonardos et al., 1987; Anda et al., 2015a, b, 2013; Shamshuddin and Anda, 2012), predominantly in the form of liming. The application of carbonate rock powder to agricultural soils is a process to adjust soil pH (Cregan et al., 1989) in order to increase crop production (Haynes and Naidu, 1998). In addition to $\mathrm{pH}$ adjustment, the additional release of cations and anions into the soil-rock system alters the chemical composition of the soil solution. Alternative amendment materials are gaining increased attention, one of which is silicate rock powder. Silicate rocks can provide geogenic nutrients via the chemical weathering of the additional minerals (Hartmann et 
al., 2013; van Straaten, 2006). Additionally, it has the potential additional advantage of enhancing atmospheric $\mathrm{CO}_{2}$ sequestration: on geological timescales, natural silicate weathering is one of the most important controls on atmospheric $\mathrm{C}$ concentrations (Berner, 2003). The silicate weathering process releases cations like $\mathrm{Mg}^{2+}, \mathrm{Ca}^{2+}$, and others, and $\mathrm{CO}_{2}$ is stored as alkalinity in the ocean, whereas carbonate weathering yields no net $\mathrm{CO}_{2}$ uptake on longer timescales (Hartmann et al., 2013). Enhanced Weathering (EW) has therefore been put forward as a method/technique with strong potential to contribute to climate mitigation. In order to achieve COP21 atmospheric $\mathrm{CO}_{2}$ concentration targets, it becomes more likely that not only emission reduction is required (Fuss et al., 2014; Rogelj et al., 2018; Peters, 2016). Focus should also be put on applying effective $\mathrm{CO}_{2}$ sequestration techniques (Sanderson et al., 2016; Beerling et al., 2018; Minx et al., 2018).

With dwindling resources of rocks with concentrated content of widely applied macronutrients, which might lead to a shortage of traditional fertilizers (Cordell et al., 2009; Manning, 2015), geogenic nutrient replacement by EW will become a valid alternative to supply not only phosphorus or potassium but also further geogenic nutrients, with potentially important local impact on food security (van Straaten, 2002; Cordell et al., 2009). In addition, alternative regional fertilizer concepts for certain regions need to be developed to enhance productivity, as for example in Africa (Ciceri and Allanore, 2019).

However, the application of silicate rock products requires knowledge of soil mineral properties, hydrology, soil solution composition, and element uptake by plants to enable predictions on its consequences. Specifically this knowledge is lacking at the broader scale (Beerling et al., 2018; Beerling, 2017; Kantola et al., 2017; Edwards et al., 2017; Taylor et al., 2017), despite several experiments in the past (Anda et al., 2015a, 2013; Shamshuddin and Anda, 2012; Shamshuddin et al., 2011). One of the main gaps is the evolution of soil solution composition and its migration in the treated soil, considering a broad variety of possible combinations of soil type, rock product, and plant species (Hartmann et al., 2013). The timescale at which changes in weathering fluxes can be expected at the scale of large catchments was shown for the Mississippi River basin, where alkalinity fluxes increased by more than $50 \%$ over less than a century, which was partly attributed to liming and land management processes (Raymond and Cole, 2003; Raymond and Hamilton, 2018). In general, past land use change and management of catchments can affect the chemical baselines of rivers draining to the ocean over decades (Hartmann et al., 2011, 2007; Meybeck, 2003; Radach and Pätsch, 2007). The large-scale application of rock products will likely lead to an alteration of river chemistry, and consequences for adjacent coastal zones remain to be assessed.

In the future, increasing food and bioenergy demand will probably lead to more efforts to improve soil conditions for optimized biomass production (Fuss et al., 2018; IPCC, 2019). The future application of customized rock products to provide slow-release geogenic nutrient fertilizers, adjust $\mathrm{pH}$, increase cation exchange capacities (CECs), or adjust soil hydrology is therefore likely. The replenishment of geogenic macro- and micronutrients is needed because the natural supply cannot keep up with the permanent removal from the soil-rock system under intensive harvest scenarios for crops or timber (de Oliveira Garcia et al., 2018; van Straaten, 2006). The application of rock products will therefore change the fluxes of elements within and from the soils, while being mediated by the biological pump.

One of the key issues is the dissolution rate of applied rock material. While the kinetics are relatively well understood at the laboratory scale for singular minerals (Rosso and Rimstidt, 2000; Wogelius and Walther, 1992), the dissolution rate of a rock powder mixture as soil amendment, with fresh surfaces, which have not been in contact with an aquatic phase before, is nearly unknown. Several points of the rock powder application on soils have to be considered. First, the upper parts of soils are not permanently saturated with water, which may lead to mineral dissolution-precipitation reactions. Second, it can be expected that mineral surfaces initially need to equilibrate with the new system and varying water content and that dissolution rates of minerals will be different from those in long-term equilibrium within the natural soil system. Third, trace elements from the applied rock material will eventually be released and migrate downwards, reprecipitated if oversaturation with a specific mineral phase occurs, or adsorbed to soil minerals or organic matter.

To understand these processes in an agricultural setting with typical crops, dunite could serve as model rock material, often containing more than $90 \%$ of olivine, a mineral often used as a model mineral to theoretically study effects of EW (Schuiling and Krijgsman, 2006; Hartmann et al., 2013; Köhler et al., 2010; Taylor et al., 2015; Renforth et al., 2015; Montserrat et al., 2017). Using near-monomineralic rocks decreases the complexity of observable effects. Discussed alternatives like basalt have a much greater complexity (considerable quantities of plagioclase and pyroxene, and to a lesser extent olivine and other trace minerals). In addition, basalt has the potential to provide the nutrient phosphorus, which is typically low in dunite. The release of phosphorus could potentially influence plant-weathering interactions in the soil, complicating the analysis of the weathering process. In our present study, we applied dunite to agricultural soils to quantify the impact on inorganic carbon and dissolved silica fluxes in the presence and absence of crop plants.

We studied the release of the major elements $\mathrm{Mg}$ and $\mathrm{Si}$ predominantly derived from $\mathrm{Mg}$ olivine, as indicators for the inorganic $\mathrm{CO}_{2}$ sequestration potential, and we assessed whether the release of elements into the soil solution occurs stoichiometrically, or whether a secondary layer covering the fresh surfaces of minerals will develop, potentially enriched in Si and depleted in Mg (Daval et al., 2013a; Hellmann et al., 
2012; Pokrovsky and Schott, 2000), which could influence weathering and subsequently sequestration rates. In addition, the release of trace metals was used to understand how these behave in a near-natural environment to evaluate the impacts on the environment.

\section{Methods}

\subsection{Mesocosm setup}

In October 2013, a fully replicated setup (five replicates per treatment combination) of mesocosms was built up and left running for $730 \mathrm{~d}$. The experimental setup was not specifically tailored to this study of weathering fluxes as we piggybacked on an experiment to evaluate elemental cycling into plants. Here we report on data of the first year. Rain barrel mesocosms with a diameter of $46 \mathrm{~cm}$ were filled with a natural loamy sandy soil from Belgium (detailed characterization including grain size distribution in Supplement S1). Controlled factors were the application of olivine-rich dunite (henceforth referred to as olivine amendment) in the top layer of the soils $\left(22 \mathrm{~kg} \mathrm{~m}^{-2}\right.$, a high mass to induce observable effects, and a similar value as the maximum mass applied in an experiment by ten Berge et al., 2012) using two different olivine grain size fractions (roughly coarse sand and fine sand to silt), two crop plants (wheat and barley), and two irrigation regimes (daily and weekly precipitation), while the total amount of rain was equal (about $800 \mathrm{~mm} \mathrm{a}^{-1}$ ). Controls were established by using the same setup without olivine application (blanks) and without plants. Waters were sampled at $1.5,12.5$, and $24.5 \mathrm{~cm}$ depth and at the bottom of the mesocosms (Fig. 1).

\subsection{Material}

The experiment material was produced from dunite rock, containing approximately $90 \%$ olivine, of which $92 \%$ was forsterite (Mg end-member olivine). The rest is comprised of lizardite (Mg-rich serpentine), Cr-bearing chlorite (including chromite or chrome-spinel inclusions), and traces of chabazite (zeolite group) and $\mathrm{Mg}$ hornblende (amphibole), determined by energy-dispersive X-ray spectrometry (Zeiss LEO 1455 VP coupled with an EDX detector by Oxford Instruments). It originates from the Almklovdalen peridotite complex (Åheim mineral deposit mined by the North Cape Minerals Company, Norway). More insights into the geochemistry of the material can be found in Hövelmann et al. (2012), and Beyer (2006) describes the geological setting. The bulk chemical composition (Panalytical Magix Pro wavelength dispersive X-ray fluorescence (XRF) analysis) of the sample is given in Table 1. The particle size distribution of the two grain size classes used was analyzed by Sympatec Helos KFMagic laser granulometry (Table 2). The sample was analyzed for specific surface area, measured using $\mathrm{N}_{2}$ and $\mathrm{Kr}$ adsorption during BET analyses (Brunauer et al.,
Table 1. Geochemical composition of source dunite, derived from XRF runs $(n=3)$.

\begin{tabular}{lrr|lrr}
\hline Oxide & Mass \% & SD & Element & $\begin{array}{r}\text { Mass } \\
\left(\mathrm{mg} \mathrm{kg}^{-1}\right)\end{array}$ & $\mathrm{SD}$ \\
\hline $\mathrm{SiO}_{2}$ & 40.14 & 0.05 & $\mathrm{Ba}$ & 55 & 9 \\
$\mathrm{Al}_{2} \mathrm{O}_{3}$ & 0.70 & 0.01 & $\mathrm{Ce}$ & 8 & 1 \\
$\mathrm{Fe}_{2} \mathrm{O}_{3}{ }^{\mathrm{a}}$ & 6.75 & 0.01 & $\mathrm{Co}$ & 105 & 2 \\
$\mathrm{MnO}$ & 0.09 & 0.00 & $\mathrm{Cr}$ & 2156 & 3 \\
$\mathrm{MgO}$ & 44.99 & 0.25 & $\mathrm{Cu}$ & 13 & 2 \\
$\mathrm{CaO}$ & 0.40 & 0.00 & $\mathrm{Ga}$ & 3 & 1 \\
$\mathrm{Na} 2 \mathrm{O}$ & 0.03 & 0.00 & $\mathrm{La}$ & 0 & 0 \\
$\mathrm{~K}_{2} \mathrm{O}$ & 0.06 & 0.00 & $\mathrm{Nb}$ & 1 & 1 \\
$\mathrm{TiO}_{2}$ & 0.01 & 0.00 & $\mathrm{Nd}$ & 29 & 5 \\
$\mathrm{P}_{2} \mathrm{O}_{5}$ & 0.01 & 0.00 & $\mathrm{Ni}$ & 2889 & 18 \\
$\mathrm{SO}_{3}$ & 0.00 & 0.00 & $\mathrm{~Pb}$ & 1 & 1 \\
$\mathrm{LOI}^{\mathrm{b}}$ & 6.48 & 0.00 & $\mathrm{Rb}$ & 4 & 2 \\
total & 99.68 & & $\mathrm{Sc}$ & 9 & 1 \\
& & & $\mathrm{Sr}$ & 56 & 1 \\
& & & $\mathrm{Th}$ & 1 & 2 \\
& & & $\mathrm{U}$ & 5 & 4 \\
& & & $\mathrm{~V}$ & 31 & 3 \\
& & & $\mathrm{Y}$ & 3 & 1 \\
& & & $\mathrm{Zr}$ & 0 & 2 \\
\hline
\end{tabular}

a Total iron $\left(\mathrm{Fe}^{2+}+\mathrm{Fe}^{3+}\right)$ is reported as $\mathrm{Fe}_{2} \mathrm{O}_{3}$. ${ }^{\text {b }}$ Loss on ignition.

1938) with a Quantachrome autosorb iQ (Table 2). Only the $\mathrm{Kr}$-based measurements were used in calculations since the use of $\mathrm{Kr}$ ensures more precise results, especially at lower surface areas (Naderi, 2015).

\subsection{Analysis}

The sampled pore and outlet waters were filtered through $0.45 \mu \mathrm{m}$ nitrocellulose Chromafil syringe filters (A-45/25) into sample bottles and stored cool $\left(4^{\circ} \mathrm{C}\right)$ until analysis. Soil material was obtained by extracting sediment cores $(20 \mathrm{~cm}$ long and $28 \mathrm{~mm}$ in diameter) using a hammer auger with a removable plastic lining (Eijkelkamp 04.15.SA foil sampler, Giesbeek, the Netherlands). In each container, one core was taken at the center. Immediately after sampling, each core was sub-sectioned into 10 slices of $2 \mathrm{~cm}$, packed in vacuum plastic bags and stored cool $\left(4^{\circ} \mathrm{C}\right)$ on return to the laboratory. Sediment samples were dried for $72 \mathrm{~h}$ at $40^{\circ} \mathrm{C}$ and homogenized by manual grinding. Three slices were analyzed: slice $2(-2$ to $-4 \mathrm{~cm}$; in dunite-amended layer), slice $6(-10$ to $-12 \mathrm{~cm}$; just below dunite-amended layer), and slice 10 $(-18$ to $-20 \mathrm{~cm}$; in untreated soil below dunite-amended layer).

\subsubsection{Silica and magnesium}

Dissolved silica $(\mathrm{Si})$ and magnesium $(\mathrm{Mg})$ were measured with an inductively coupled plasma atomic emission spec- 


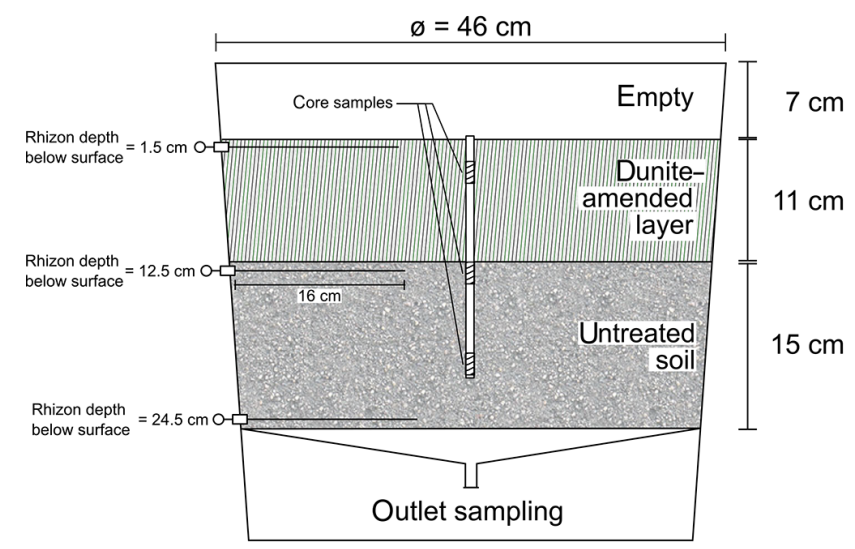

(a)

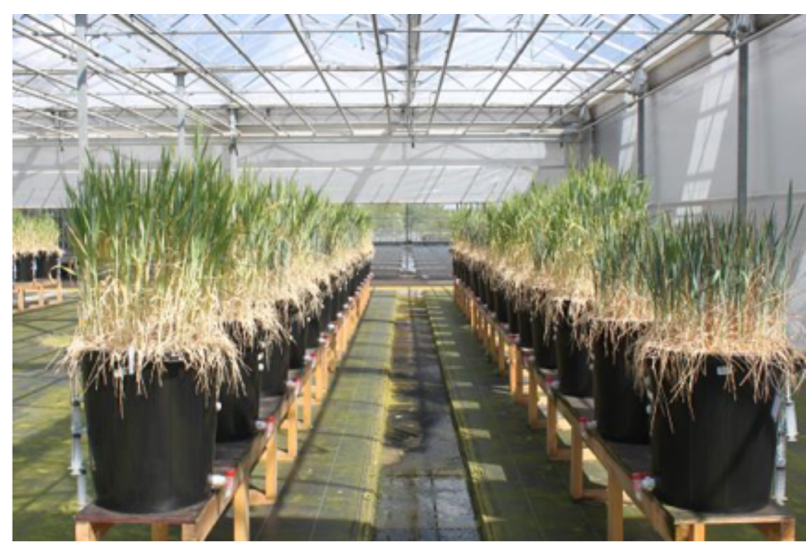

(b)

Figure 1. (a) Schematic mesocosm configuration; (b) status of the experiment in April 2014 (6 months in).

Table 2. Specific surface area of the source material, derived by BET analyses, as well as grain size distribution characteristics.

\begin{tabular}{lrrrrrrr}
\hline $\begin{array}{l}\text { Grain size } \\
\text { category }\end{array}$ & $\begin{array}{r}\text { Specific surface } \\
\text { area, N based } \\
\left(\mathrm{m}^{2} \mathrm{~g}^{-1}\right)\end{array}$ & $\begin{array}{r}\text { Specific surface } \\
\text { area, Kr based } \\
\left(\mathrm{m}^{2} \mathrm{~g}^{-1}\right)\end{array}$ & $\begin{array}{r}\mathrm{p}^{-1} 0^{\mathrm{a}} \\
(\mu \mathrm{m})\end{array}$ & $\begin{array}{r}\text { Dominating } \\
\text { class } \\
(\mu \mathrm{m})\end{array}$ & $\begin{array}{r}\text { Share of } \\
\text { dominating } \\
\text { class }(\%)\end{array}$ & $\begin{array}{r}\text { Smallest } \\
\text { class } \\
(\mu \mathrm{m})\end{array}$ & $\begin{array}{r}\text { Share of } \\
\text { smallest } \\
\text { class }(\%)\end{array}$ \\
\hline Fine & $9.53 \pm 0.43$ & $14.75 \pm 0.24$ & 43.5 & 25.5 & $6.7 \pm 0.02$ & $<0.9^{\mathrm{c}}$ & $2.66 \pm 1.51$ \\
Coarse & $1.06 \pm 0.10$ & $1.61 \pm 0.03$ & 1020 & 720 & $10.8 \pm 0.7$ & $<18$ & $1.51 \pm 0.03$ \\
\hline
\end{tabular}

a Sieve mesh at which $20 \%$ is retained; thus $80 \%$ is smaller than the given diameter. ${ }^{\mathrm{b}}$ Class with the largest class weight. ${ }^{\mathrm{c}}$ This class is divided into five smaller classes but was summed to show the share below $1 \mu \mathrm{m}$.

trophotometer (ICP-AES, Thermo Scientific, ICAP 6000 series).

\subsection{2 pH}

Water from the bottom outlet was drained into a bucket and $\mathrm{pH}$ was measured using a WTW $\mathrm{pH}$ meter, calibrated with three NIST buffer standards ( $\mathrm{pH} \mathrm{4,} \mathrm{7,} \mathrm{and} \mathrm{10).}$

\subsubsection{Trace metals}

In the soil solution as well as in the soil material, concentrations of aluminum $(\mathrm{Al})$, barium $(\mathrm{Ba})$ chromium $(\mathrm{Cr})$, cobalt $(\mathrm{Co})$, iron $(\mathrm{Fe})$, manganese $(\mathrm{Mn})$, nickel $(\mathrm{Ni})$, strontium $(\mathrm{Sr})$, and zinc ( $\mathrm{Zn}$ ) were analyzed using inductively coupled plasma atomic emission spectroscopy (ICP-AES, Optima 2100, PerkinElmer).

For analysis of the total content of substances within the soil material, a digestive procedure was followed according to Heinrichs and Herrmann (2013). In brief, soil was dried at $40^{\circ} \mathrm{C}$ and milled with a planetary ball mill. A total of $150 \mathrm{mg}$ of soil was weighed into PTFE crucibles and a mixture of $4 \mathrm{~mL}$ nitric acid (65\% Suprapur grade), $2 \mathrm{~mL}$ hydrofluoric acid (40\% Suprapur grade), and $2 \mathrm{~mL}$ perchloric acid (70\% Suprapur grade) was added. The crucibles were sealed and placed for $10 \mathrm{~h}$ in a closed digestion aperture (PicoTrace $\mathrm{GmbH}$ ) at $170^{\circ} \mathrm{C}$ to ensure complete dissolution.
Subsequently, the acids were vaporized in a closed system and the residues were dissolved with $2 \mathrm{~mL}$ nitric acid $(65 \%$ Suprapur grade), $0.6 \mathrm{~mL}$ hydrochloric acid (37\% Suprapur grade), and $20 \mathrm{~mL}$ high-purity water at $90^{\circ} \mathrm{C}$ for $1 \mathrm{~h}$. The solutions were standardized to $50 \mathrm{~mL}$ with high-purity water and underwent atomic emission spectroscopy (ICP-AES) as described above.

\subsubsection{Dissolved inorganic carbon (DIC)}

DIC was measured with a Picarro G2131-i cavity ring-down spectrometer coupled to a preparation device (AutoMate FX, Inc.) for discrete sample measurement. Enough sample volume was not available for DIC analyses at all sampling times, as priority was given to other major compounds based on the original purpose of the experiment. Samples were preserved with $\mathrm{HgCl}_{2}$ and stored dark and cool until analysis.

\subsection{Calculation of weathering and $\mathrm{CO}_{2}$ sequestration rate}

The average flux of $\mathrm{Mg}$ from dunite-amended soils at the outlet can be calculated by

$$
\text { flux }_{\mathrm{Mg}^{2+}}=\left(\left[\mathrm{Mg}^{2+}\right]_{\text {treated }}-\left[\mathrm{Mg}^{2+}\right]_{\text {untreated }}\right) \times q,
$$


with $q$ as water volume discharged at the outlet per sampled time interval.

The sequestration rate can subsequently be calculated by

$$
\begin{aligned}
\mathrm{CO}_{2} \text { sequestration } & =\frac{\text { flux }_{\mathrm{Mg}^{2+}} \times \text { molweight }_{\mathrm{Mg}}}{\text { fraction of } \mathrm{Mg} \text { in olivine }} \\
& \times \mathrm{RCO}_{2} \times \omega
\end{aligned}
$$

with a fraction of $\mathrm{Mg}$ in olivine of about 1.8 (inferred from $\mathrm{XRF}$ analysis, Table 1). $\mathrm{RCO}_{2}$ is the theoretical maximum uptake of $\mathrm{CO}_{2}$ in metric tons per metric ton of rock (1.25), which is corrected by $\omega(=0.85)$, to account for carbonate system equilibration in the ocean (after Renforth, 2012; Renforth et al., 2013, and references therein). The global $\mathrm{CO}_{2}$ sequestration potential was then calculated by multiplying with the available arable land in an optimistic and a pessimistic scenario (Moosdorf et al., 2014).

The weathering rate can be estimated by

$$
\begin{aligned}
& \text { weathering rate } R\left[\frac{\mathrm{mol} \text { olivine }}{\mathrm{m}^{2} \mathrm{~s}}\right]
\end{aligned}
$$

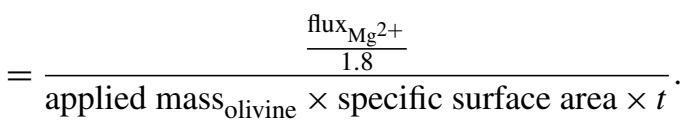

The numerator converts the molar flux of $\mathrm{Mg}$ to molar flux of olivine ( $1.8 \mathrm{~mol} \mathrm{Mg}$ per $1 \mathrm{~mol}$ olivine). Time factor $t$ is used to convert the flux measured in $340 \mathrm{~d}$ to seconds.

\subsection{Calculation of the amorphous Si layer}

The Mg-depleted and Si-enriched layer that forms during the dissolution process (Daval et al., 2011) was roughly estimated using the release of $\mathrm{Mg}$ in conjunction with the $\mathrm{Mg} / \mathrm{Si}$ ratio and the available surface area of the forsterite.

The mass of $\mathrm{SiO}_{2}$ that precipitated per square meter and year as amorphous $\mathrm{Si}$ can be estimated by

$$
\begin{aligned}
m_{\mathrm{SiO}_{2} \text { amorph. }}\left[\frac{g \mathrm{SiO}_{2}}{\mathrm{~m}^{2} \mathrm{a}}\right] & =\left(\frac{R_{\mathrm{Mg}}}{\mathrm{Mg} / \mathrm{Si}_{\text {theoretical }}}-R_{\mathrm{Si}}\right), \\
& \times M_{\mathrm{SiO}_{2}} \times t,
\end{aligned}
$$

with the dissolution (weathering) rates $R_{\mathrm{Mg}}$ and $R_{\mathrm{Si}}$ calculated from experimental data, the theoretical $\mathrm{Mg} / \mathrm{Si}$ ratio (1.8), $M_{\mathrm{SiO} 2}$ as the molar mass of $\mathrm{SiO}_{2}$, and time factor $t$ to convert seconds to years.

The depletion layer thickness can then be calculated as

$$
\begin{aligned}
& \text { growth rate of } \mathrm{SiO}_{2} \text { layer }\left[\frac{\mathrm{nm}}{\mathrm{a}}\right] \\
& =\frac{m_{\mathrm{SiO}_{2_{\mathrm{a}} \text { morph. }}}}{\rho_{\mathrm{SiO}_{2_{\text {amorph. }}}} \times\left(1-\varphi_{\left.\mathrm{SiO}_{2_{\text {amorph. }}}\right)}\right)} \times 10^{9},
\end{aligned}
$$

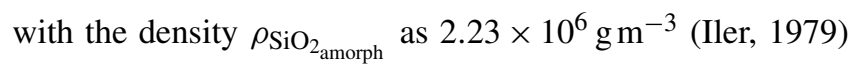

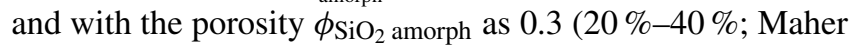
et al., 2016).

\section{Results}

\subsection{Hydrology}

Two rain regimes, with daily and with weekly rainfall, delivering the same total annual precipitation volume, were used. Since there were no significant and/or systematic differences between results of both rain treatments (Fig. S2-1 in the Supplement), all discussed data integrate values from both rain treatments. After the experiment start, it took between 7 and $23 \mathrm{~d}$ until water reached the bottom of the mesocosms. The amount of irrigation water and the water collected at the outlet of each barrel were used to roughly estimate the loss of water through evaporation and transpiration, not accounting for water storage in biomass and changes in soil water storage capacity. Sample volume which could be extracted varied. Between days 200 and 300, growth of plants and elevated ambient temperatures caused strong evapotranspiration, which reduced the outflowing water volume to a minimum. At these times, no or only a little sample volume could be obtained. Data clearly show elevated evapotranspiration in the mesocosm seeded with crops (Fig. 2).

\subsection{Release patterns of weathering tracers}

The fine-olivine fraction shows about a 9-fold higher specific surface area in both krypton- and nitrogen-based measurements than the coarse fraction (Table 2). Observed results are therefore differentiated by fine- and coarse-rock treatment. Elevated concentrations of the major studied parameters DIC, $\mathrm{Mg}$, and Si are only observed at 1.5 and $12.5 \mathrm{~cm}$ depth, with the largest increase in the top sampling point if compared to the base level setup without olivine. Changes in DIC and $\mathrm{Mg}$ concentrations are most pronounced in the mesocosms supplied with fine-olivine amendment, with values markedly above base concentrations in the setup with coarser olivine (Figs. 3, 5). A pronounced increase in $\mathrm{pH}$ at the beginning of the experiment (Fig. 4), with values near 9 for the fine-grain-size setup, can be observed. If values are compared against untreated mesocosms, the $\mathrm{pH}$ of soil solutions increases by up to 1.0 and $0.3 \mathrm{pH}$ units in mesocosms treated with fine and coarse olivine, respectively (Fig. S14-1 in the Supplement). Over the course of the experiment, the observed $\mathrm{pH}$ approaches values around 8 . Depending on the setup, the $\mathrm{pH}$ in the fine setup is about $0.5 \mathrm{pH}$ units higher than in the others after 1 year. Si concentrations develop dissimilarly, with most pronounced increases in the coarse setup, whereas the fine setup releases less than half of the $\mathrm{Si}$ into the soil solution in the surface level, i.e., at $1.5 \mathrm{~cm}$ depth (Fig. 6). The effect is less obvious in the second sampled depth at $12.5 \mathrm{~cm}$, and no changes are visible below. Interestingly the Si concentrations in the top sampling for treatments with the fine material are also lower than if no olivine was supplied. With the exception of visible differences in Si concentrations, with lower values in the setups with plants, no 

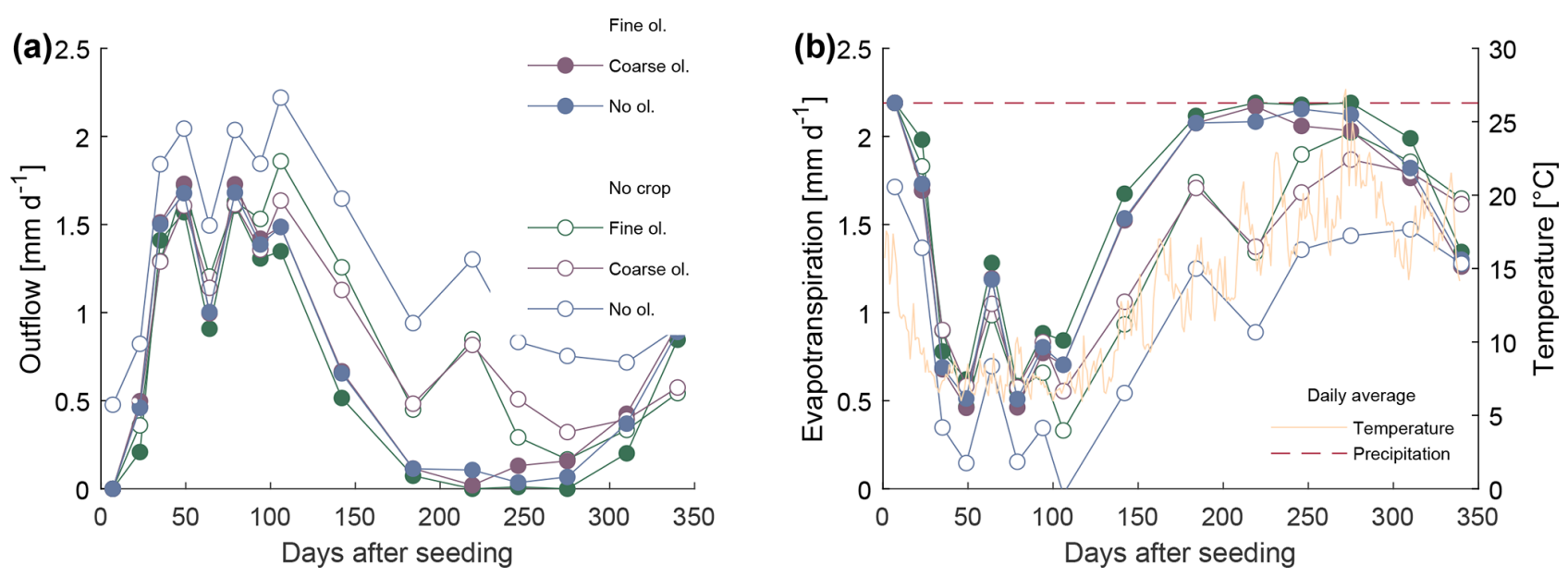

Figure 2. (a) Water flow from outlet; values refer to daily fluxes from the preceding interval. (b) Average daily temperature in the greenhouse and evapotranspiration, calculated from the difference of precipitation input and barrel outflow, relative to precipitation.

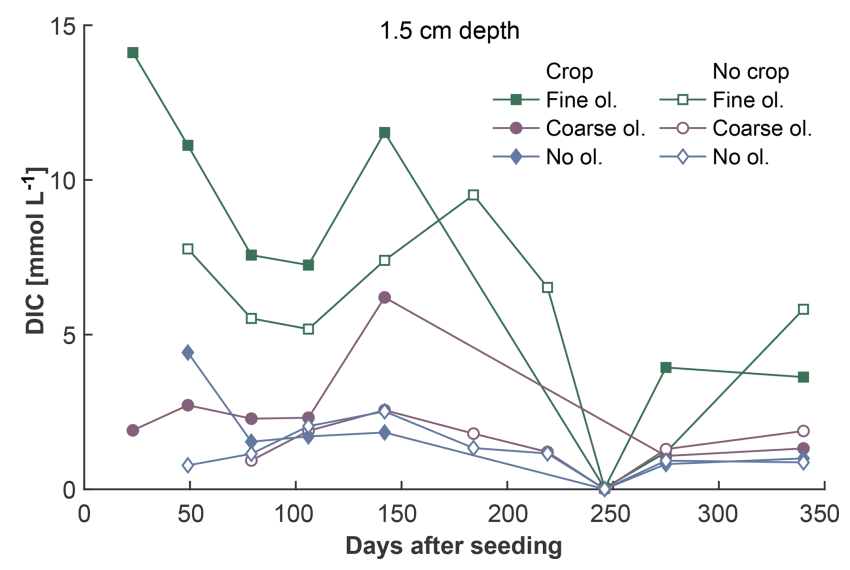

Figure 3. Development of average DIC concentrations over 1 year at $1.5 \mathrm{~cm}$ depth, differentiated by olivine and crop treatment. For more information on the subsequent layers and error bars, please refer to Fig. S3-1 in the Supplement.

clear difference pattern can be identified if crop plants are present (Figs. 3-6 and S3-1 to S6-1). The general pattern is a large variation in concentrations, suggesting that the variability between mesocosms is high and that five replicas per setup are probably not enough to derive a differentiated signal as presented for the major element concentrations. Despite the large variability, it is clear that the weathering signal from the amended olivine travels slowly downwards in the soil pore space. Within the first year, it was not moving much beyond the $12.5 \mathrm{~cm}$ level, as elevated $\mathrm{Mg}$ concentrations, which provide the clearest signal for olivine dissolution, were not clearly detectable at the third level $(24.5 \mathrm{~cm})$, with two exceptions in the case of the fine-grain setup.

Generally, $\mathrm{Mg} / \mathrm{Si}$ is clearly above 2 at the 1.5 and $12.5 \mathrm{~cm}$ levels below surface in mesocosms amended with fine olivine. The ratio is roughly in the range of $1-10$ in the

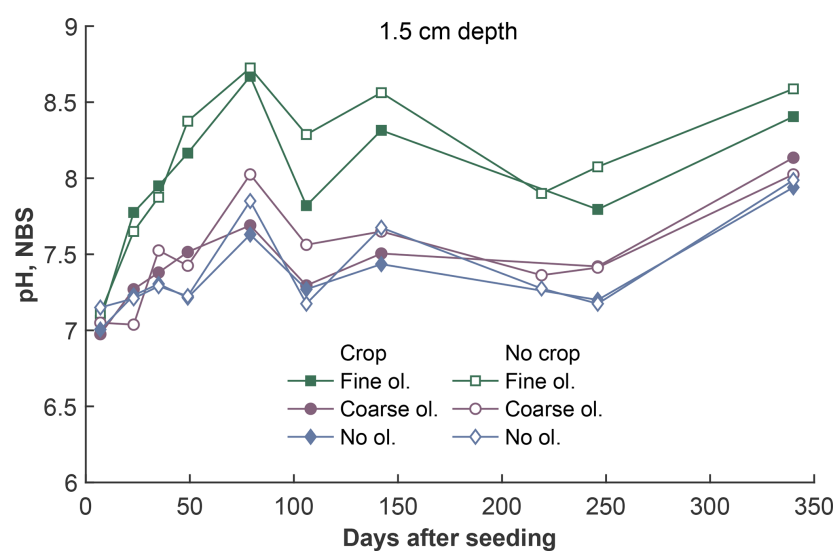

Figure 4. Development of $\mathrm{pH}$ values (averaged proton concentrations, converted to $\mathrm{pH}$ ) over the experiment period at $1.5 \mathrm{~cm}$ depth, differentiated by olivine and crop treatment. For more data and error bars, please refer to Fig. S4-1.

lower sampled depths of fine treatments and in all depths of the setups without coarse and no olivine (Fig. 7). Shortly after the start of the experiment $\mathrm{Mg} / \mathrm{Si}$ ratios (Fig. 7) are high $(\mathrm{Mg} / \mathrm{Si}>50)$ in the soil water at the surface of the fine-grain treatment, due to a strong increase in $\mathrm{Mg}$ and the comparably low increase in $\mathrm{Si}$. The effect is weaker for the coarse-grain treatment $(\mathrm{Mg} / \mathrm{Si}<30$, but still above 2$)$. There is no distinct difference in $\mathrm{Mg} / \mathrm{Si}$ in the three setups (fine, coarse, no olivine) in the deepest soil sampling point and the outlet (with the exception of two outlier points in the deepest sampled layer for the fine olivine with crop setup).

\section{3 $\mathrm{CO}_{2}$ sequestration rates}

Ideally, the $\mathrm{CO}_{2}$ consumption by weathering can be calculated based on DIC or alkalinity. As too few samples were available for DIC analysis, the additional $\mathrm{CO}_{2}$ consump- 

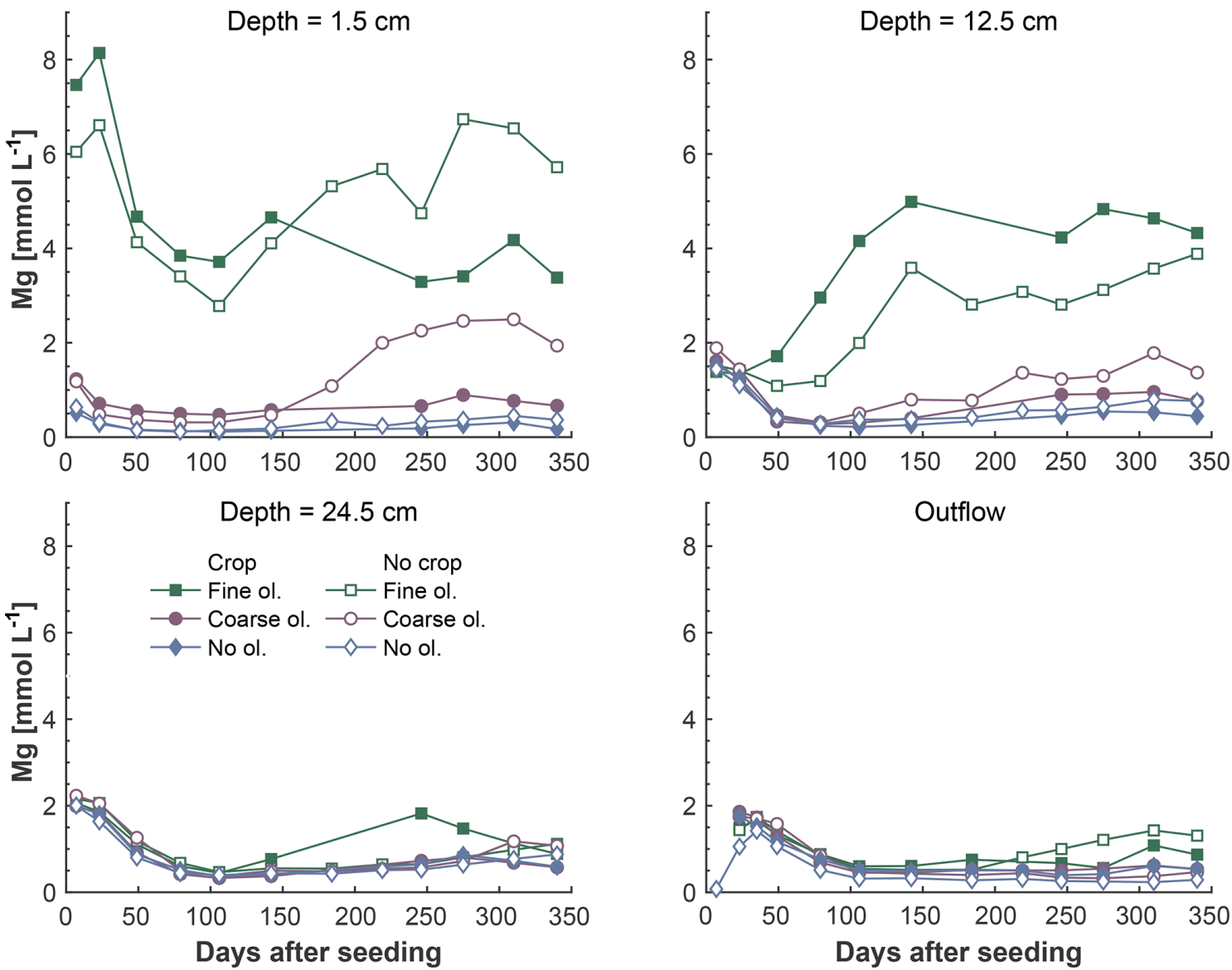

Figure 5. Development of $\mathrm{Mg}$ concentrations over the experiment period, differentiated by olivine and crop treatment. Data points are averages but error indicators were omitted to provide a better overview. For a more differentiated view and standard deviations, please refer to Fig. S5-1.

tion by olivine amendment was calculated based on the release of $\mathrm{Mg}^{2+}$, considering the average geochemical composition of the material and the background values from applied soils and irrigation water. Based on the stoichiometric composition, the ideal dissolution of $1 \mathrm{~mol} \mathrm{Mg}$ olivine yields $2 \mathrm{~mol} \mathrm{Mg}$ and consumes $4 \mathrm{molCO}_{2}$ :

$\mathrm{Mg}_{2} \mathrm{SiO}_{4}+4 \mathrm{H}_{2} \mathrm{O}+4 \mathrm{CO}_{2} \rightarrow 2 \mathrm{Mg}^{2+}+4 \mathrm{HCO}_{3}^{-}+\mathrm{H}_{4} \mathrm{SiO}_{4}$.

The ability to sequester atmospheric $\mathrm{CO}_{2}$ is material specific and depends here on the $\mathrm{Mg}^{2+}$ that can be released during hydrolysis from the Mg-rich olivine. It is defined as the carbon dioxide removal $\left(\mathrm{RCO}_{2}\right)$ in metric tons of $\mathrm{CO}_{2}$ per metric ton of $\mathrm{Mg}$ olivine (estimated to be 1.1 for ultramafic (i.e., $\mathrm{Mg}$ rich) rocks; Moosdorf et al., 2014). This assumption considers that impurities (like $\mathrm{Fe}$ abundance), in contrast to the ideal $\mathrm{Mg}$ olivine and equilibration effects, reduce the theoretical maximum $\mathrm{RCO}_{2}$ of 1.25 for forsterite. Based on the average of $\mathrm{Mg}$ concentrations in the outlet water over the first year $(340 \mathrm{~d})$, the experiment leads to a total annual $\mathrm{CO}_{2}$ sequestration of $2.3-4.9 \mathrm{tCO}_{2} \mathrm{~km}^{-2} \mathrm{a}^{-1}$, depending on the applied grain size (Table 3 ).
To evaluate the potential order of magnitude of $\mathrm{Mg}$ uptake or dilution, possibly introduced by the experimental setup, $\mathrm{Mg}$ concentrations in the outlet water might be compared to those in the surface layer pore water. The ratio of surface layer $\mathrm{Mg}$ concentration to outlet $\mathrm{Mg}$ concentration is 12.2 in the coarse setup and 13.8 in the fine setup (Table 3).

\subsection{Trace metals}

\subsubsection{Soil}

Analyses of the soil elemental composition show that some trace element concentrations are elevated, where olivine was applied (Fig. 8). Markedly, this is the case for $\mathrm{Co}, \mathrm{Cr}, \mathrm{Ni}, \mathrm{Mn}$, $\mathrm{Al}$, and $\mathrm{Fe}$. There are no statistically significant differences between the applied grain sizes and crop types.

\subsubsection{Soil solution}

$\mathrm{Ni}$ and $\mathrm{Cr}$ concentrations in the soil solution are elevated in the surface layer where fine olivine grain sizes were applied (Fig. 9) during the first $100 \mathrm{~d}$. The coarse-grain setup does not 

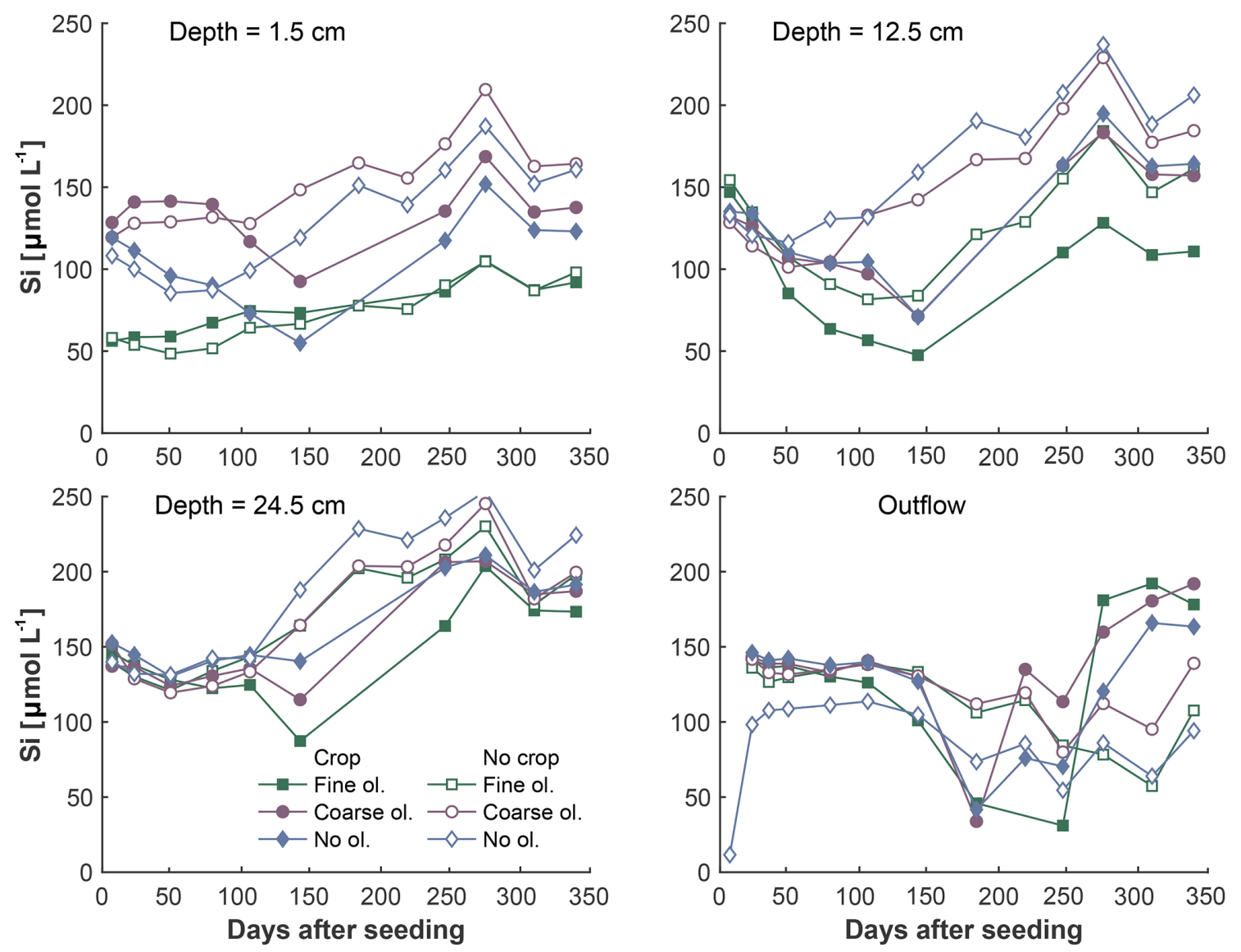

Figure 6. Development of Si concentrations over the experiment period in the surface layer, differentiated by olivine and crop treatment. Data points are averages, but error indicators were omitted to provide a better overview. For a more differentiated view and standard deviations, please refer to Fig. S6-1.

Table 3. $\mathrm{Mg}$ and water flux averages $( \pm \mathrm{SD})$ throughout the period of the experiment, excluding background contributions from soil and irrigation water, for crop and no crop treatment. The potential of $\mathrm{Mg}$ removal and its effect on $\mathrm{CO}_{2}$ consumption is provided, assuming that all water would percolate the pore space of the upper soil and equilibrate towards the measured $\mathrm{Mg}$ concentrations. Details on the calculation of $\mathrm{CO}_{2}$ consumption are found in Sect. 2.4.

\begin{tabular}{|c|c|c|c|c|c|c|}
\hline & \multicolumn{2}{|c|}{$\operatorname{Mg}\left(\mu \mathrm{mol} \mathrm{L}^{-1}\right)$} & $\mathrm{Mg}$ reduction ratio ${ }^{\mathrm{a}}$ & Water flux at outlet $\left(\mathrm{Ld}^{-1}\right)$ & \multicolumn{2}{|c|}{$\mathrm{CO}_{2}$ consumption $\left(\mathrm{tCO}_{2} \mathrm{~km}^{-2} \mathrm{a}^{-1}\right)$} \\
\hline Fine & $4713.1 \pm 1128.2$ & $357.8 \pm 238.1$ & $13.8 \pm 7.4$ & $0.8 \pm 0.6$ & 4.9 & 67.6 \\
\hline
\end{tabular}

${ }^{a}$ Calculated directly from original $\mathrm{Mg}$ concentrations per sample time step (not averages, hence the slight difference to the ratio of average $\mathrm{Mg}$ concentrations from the first two columns). Data were taken only from day 79 onwards because fluctuations were too inconsistent in the first weeks of the experiment. ${ }^{b}$ Calculated net flux from mesocosm based on observed $\mathrm{Mg}$ concentrations in the outflow. ${ }^{\mathrm{c}} \mathrm{CO}_{2}$ consumption "observed" at outlet multiplied with reduction ratio to account for Mg removal or dilution.

show any visible $\mathrm{Cr}$ concentration difference compared to the control; Ni concentrations in barrels amended with olivine are higher than in the mesocosms without olivine on average (Fig. 9). The existence of plants does not cause a distinct pattern change in any setup compared to no-plant treatments. Base values of $\mathrm{Cr}$ without olivine treatment are already above $50 \mathrm{nmol} \mathrm{L}^{-1}$. The dissolution of dunite predominantly leads to elevated levels of $\mathrm{Ni}$ and $\mathrm{Cr}$ concentrations in the soil solution over the control (Fig. S11-1.).

For the other trace elements, no distinct pattern between treatments with and without olivine was identified, apart from a general variability found in the solutions. 

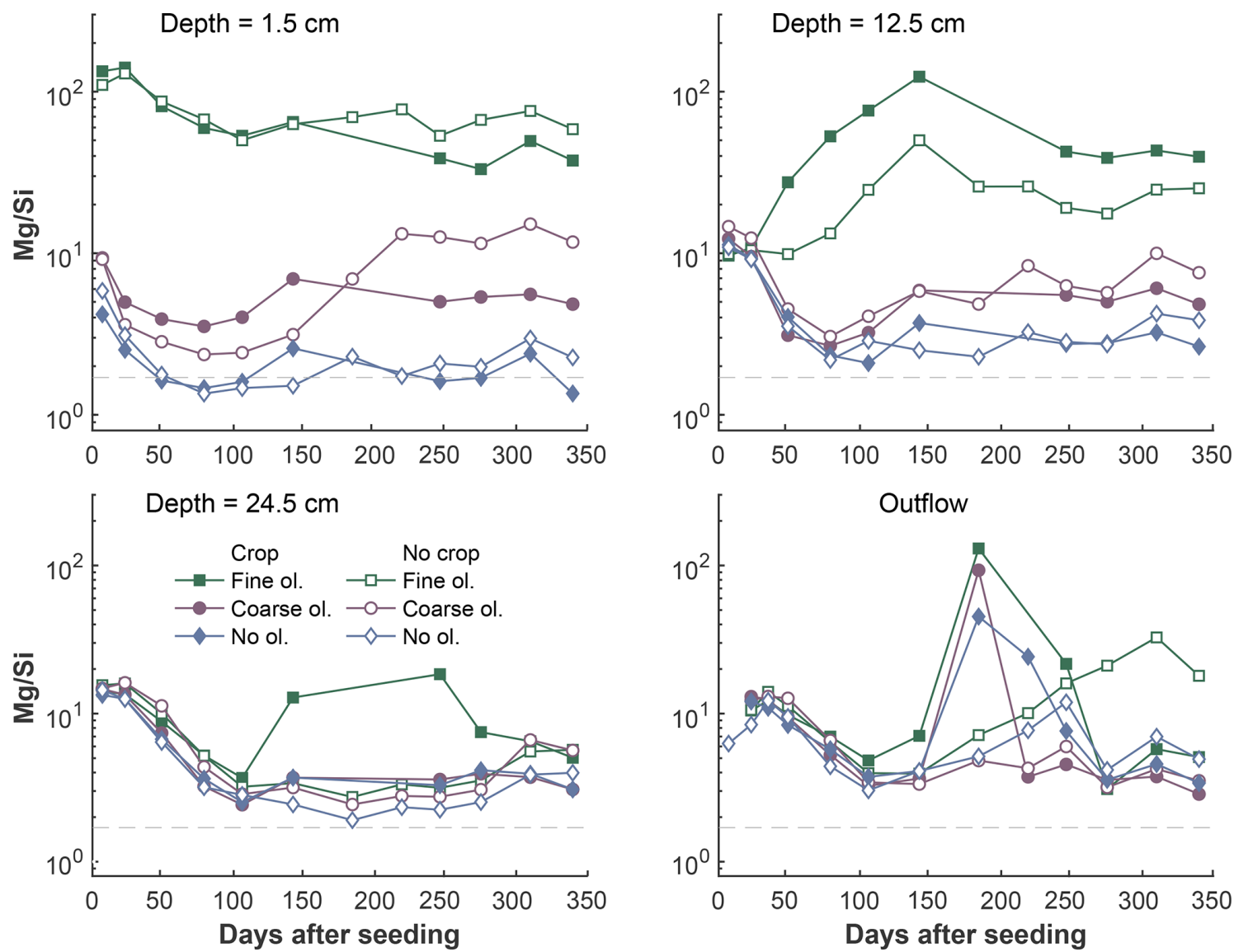

Figure 7. Development of $\mathrm{Mg} / \mathrm{Si}$ ratios over the experiment period in the surface layer, differentiated by olivine and crop treatment. The dashed grey line indicates the stoichiometric $\mathrm{Mg} / \mathrm{Si}$ ratio of 1.8 based on the rock chemistry. Data points are averages but error indicators were omitted to provide a better overview. For a more differentiated view and standard deviations, please refer to Fig. S7-1.

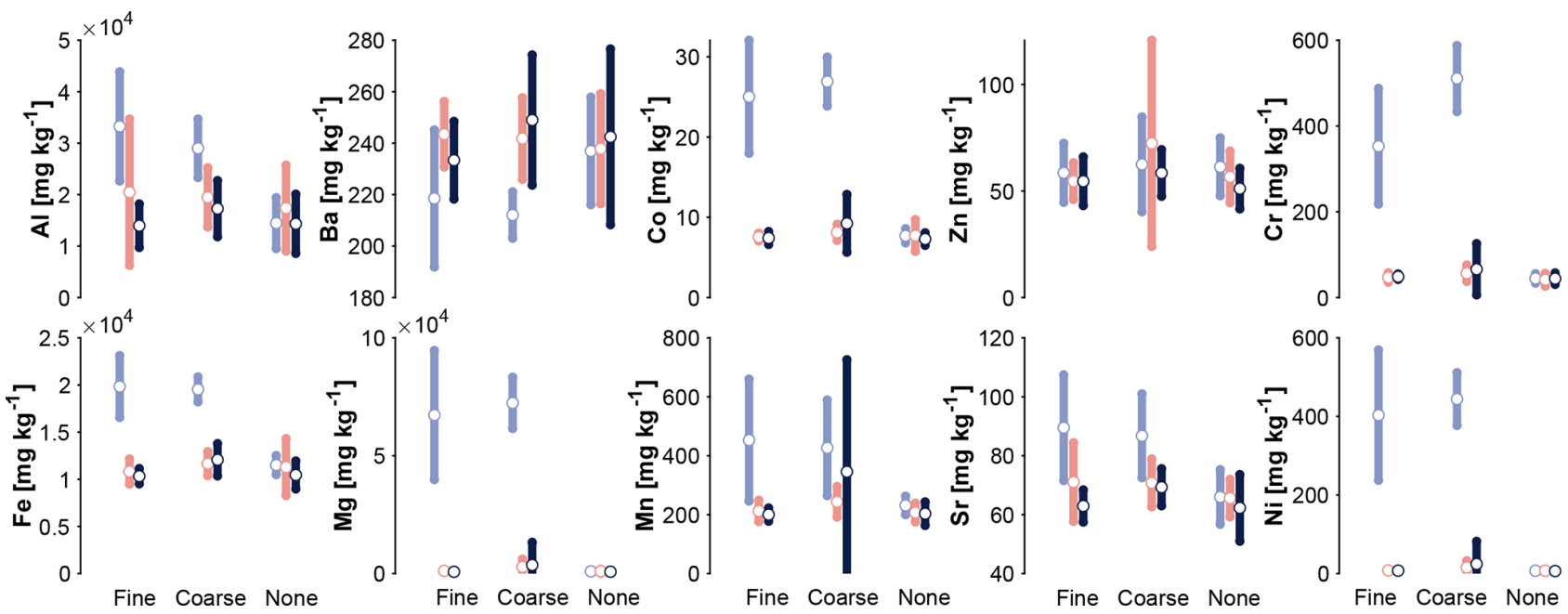

Figure 8. Averaged trace element concentrations in the solid soil material, differentiated by olivine treatment (grouping) and depth (blue: 2-4 cm; red: $10-12 \mathrm{~cm}$; black: $18-20 \mathrm{~cm}$ below surface). Error bars indicate 1 standard deviation. Data are separated by plant type in Supplement S8 (topsoil only). 

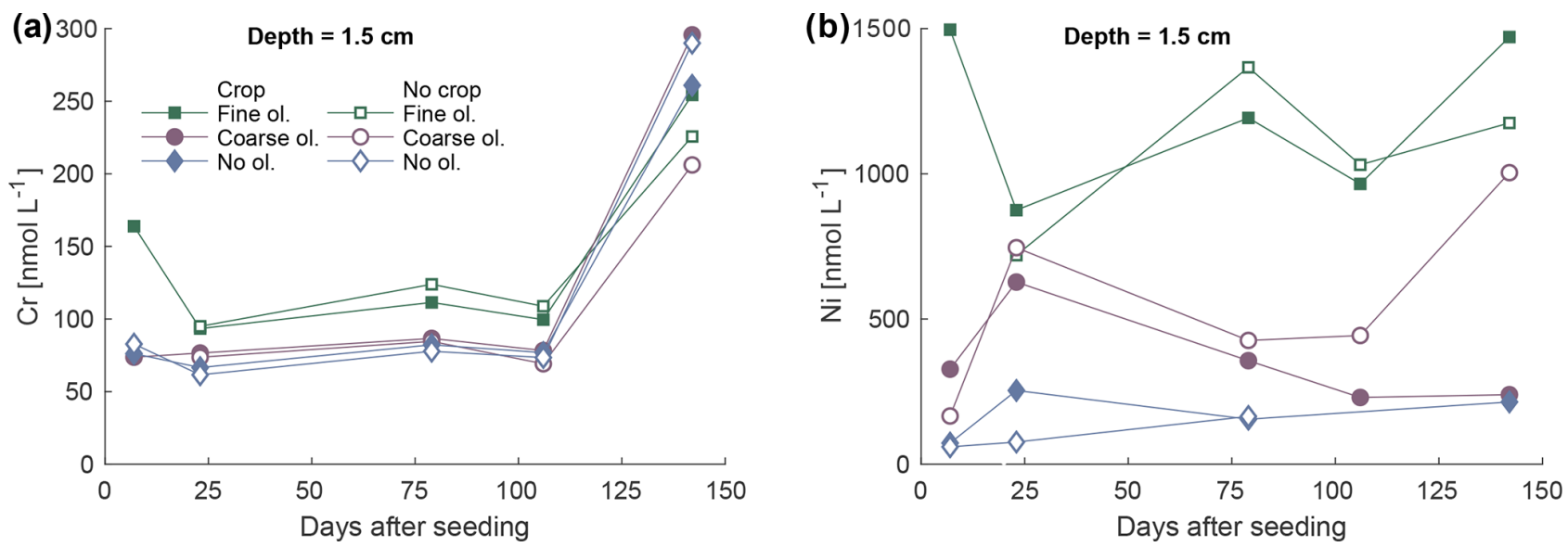

Figure 9. Development of $\mathrm{Cr}$ (a) and $\mathrm{Ni}$ (b) concentrations in soil pore water over the first 5 months in the layer $1.5 \mathrm{~cm}$ below the surface, differentiated by olivine and crop treatment. For more data and error bars, please refer to Figs. S9-1 and S10-1.

\section{Discussion}

\subsection{Tracing the weathering effect}

Based on the released Mg and BET surface area measurements of the ground rock material, weathering rates can be estimated (see Sect. 2.4). Derived rates of $10^{-13.12}$ and $10^{-13.75} \mathrm{molOl} \mathrm{m}^{-2} \mathrm{~s}^{-1}$ for coarse and fine material, respectively, based on the outlet water, are about 1 order of magnitude lower than values published for an olivine-amended soil column experiment (Renforth et al., 2015) and about 3 orders of magnitude lower than theoretical optimum dissolution rates given in Strefler et al. (2018). These differences are not unexpected, considering that $\mathrm{Mg}$ is not acting conservatively, and our experimental setup simulates natural processes like extended periods of drying out, with potential secondary mineral formation, and subsequent slowed-down or ceased chemical weathering processes, as well as cation exchange, and dilution by preferential flow.

The large difference in available surface area for reaction between fine and coarse material (Table 2) has implications for the release rate of elements as it is proportional to the available surface area. Averages of $\mathrm{Mg}$, with the clearest dissolution signal, show a strong difference between $\mathrm{Mg} / \mathrm{Si}$ release ratios of the fine- and coarse-material setups, suggesting that the dissolution of the dunite and predominantly olivine is clearly not stoichiometric. This was also observed in results from laboratory experiments (Pokrovsky and Schott, 2000). We assume that the potential formation of cation-depleted silica layers around minerals might affect the dissolution rates. Further effects are related to the distribution of water in the pore space, which is steered by grain size distribution effects, via differences of the water contact time with grain surfaces. Also, climatic conditions lead to dryingup during the warm period in the greenhouse caused by evapotranspiration under presence of plants, resulting in low soil water content and varying elemental concentrations in the remaining water. If the $\mathrm{Mg} / \mathrm{Si}$ ratio is 2 , the ideal stoichiometric molar ratio of element release from forsteritic olivine is reached. In the case of the applied material, the $\mathrm{Mg} / \mathrm{Si}$ ratio is about 1.8 (inferring from XRF results). The experimental data show that $\mathrm{Si}$ and $\mathrm{Mg}$ concentrations in the upper layer are often decreased if plants were present (Figs. 5, 6). But even with this effect, $\mathrm{Mg} / \mathrm{Si}$ ratios are still far from the equilibrium release ratio of 1.8. This effect is widely recognized as incongruent dissolution (Casey et al., 1993; Ruiz-Agudo et al., 2012). Considering that there are large amounts of $\mathrm{Mg}$ released, Si determines the ratio assuming that removal by plants is minor. This suggests that there is an active retention of $\mathrm{Si}$, potentially leading to a cation-depleted amorphous silica layer growing around olivine minerals (Daval et al., 2013b, 2011; Hellmann et al., 2012). This effect has been described in detail for forsterite by Maher et al. (2016). High $\mathrm{Mg} / \mathrm{Si}$ ratios indicate that in the beginning of the experiment the dissolution rate is controlled by the exchange of protons for $\mathrm{Mg}$, while declining ratios over the course of the experiment indicate an approach to steady-state conditions (Maher et al., 2016). Since this effect may eventually determine the $\mathrm{CO}_{2}$ sequestration rate, an estimation of the thickness of those layers would lead to a better understanding of weathering kinetics for silicate application schemes in general, as this process may affect other silicate minerals too. From the mesocosm experiments, it is only feasible to calculate a rough 1st-order estimate given the rather basic setup of the mesocosms. Calculated amorphous layer growth rates (details Sect. 2.5) for the mesocosms without plants range from $0.02 \mathrm{nma}^{-1}$ (fine setup) to $0.08 \mathrm{nma}^{-1}$ (coarse setup). These values are above or near observations of surface layers around "aged" minerals, e.g., from Hellmann et al. (2012): $14.7 \mathrm{kyr}$ old feldspar with a surface layer of $50 \mathrm{~nm}$ $\left(\approx 0.0034 \mathrm{~nm} \mathrm{a}^{-1}\right)$ and a layer of $150-200 \mathrm{~nm}$ on a younger (assuming $10 \mathrm{kyr}$ ) serpentine $\left(\approx 0.02 \mathrm{nma}^{-1}\right)$. However, if 
assuming that the fresh surfaces of the forsterite are weathering faster in the beginning and a decrease in reaction rate can be caused by the formation of the amorphous layer due to processes related to the diffusion of released elements through the layer (Nugent et al., 1998; Daval et al., 2013b), this might explain why the calculated growth rates are comparable to aged material, as with time weathering rates decrease.

As the formation of a secondary layer through Si reprecipitation should preferentially include Si previously released by the amended material, this process alone cannot explain why Si concentrations in the fine setup are about 2 -fold below values of the control setup without olivine and without plants (Fig. 6). We speculate that the increased release of $\mathrm{Si}$ from the finest grains leads to short-term oversaturation of $\mathrm{Si}$ (about $1.9 \mathrm{mmolL}^{-1}$ at $25^{\circ} \mathrm{C}$; Stumm and Morgan, 1996), extending beyond the typical area of the secondary silica layer formation around the grains, which may facilitate the formation of secondary minerals such as smectites (Prudêncio et al., 2002) or a mixture of different hydrous silicates of iron and magnesium, known as iddingsite (Smith, 1987).

\section{2 $\mathrm{CO}_{2}$ sequestration by olivine amendment}

The $\mathrm{pH}$ increase, as an indicator of rock dissolution of silicates, is most pronounced in the upper layer and during the first 6 months of the experiment. This indicates an enhanced reaction with the added rock powder, which contains a large fraction of very fine material, providing an increased reactive surface area. The effect indicates the generation of alkalinity by chemical weathering consuming $\mathrm{CO}_{2}$ and can partly be seen in the DIC concentrations for the fine-grain experiments (Fig. 3). As DIC was handled with the lowest priority during the sampling campaign (regarding low sampling volumes), only a few measurements are available, which makes it hard to truly differentiate the treatments based on DIC.

Due to limits in the acquired data, it is only possible to give a rough estimate of the $\mathrm{CO}_{2}$ drawdown effect by weathering. The elevated elemental concentrations from the surface sample point do not progress evenly downwards, which means that several processes influence $\mathrm{Mg}$ concentrations during percolation. A $\mathrm{Mg}$ concentration difference between surface soil pore water and outflow of about an order of magnitude could primarily stem from element removal by plants, mineral precipitation, de-mobilization by cation absorption through clay minerals, or dilution through preferential flow along soil macropores and the rims of the mesocosm barrel. Significant and systematic Mg removal by plants might be ruled out, as differences between $\mathrm{Mg}$ concentrations of the surface pore waters in planted and unplanted mesocosms are mostly not significant (Fig. S5). As Mg in the surface layer and the outflow increases in nearly all treatment types when evapotranspiration values rise due to increasing temperatures from around day 100 on, a process also observed in another mesocosm experiments (Thaysen et al., 2014), the loss of $\mathrm{Mg}$ by secondary mineralization can be assumed but not quantified. However, the precipitation of $\mathrm{Mg}$ carbonates at ambient conditions is kinetically hindered (Case et al., 2011; Giammar et al., 2005), and therefore the $\mathrm{Mg}$ removal effect is potentially small for carbonates in the mesocosm environment, but further investigation for amorphous phases or precursors for secondary mineral formation would be necessary.

The soil is characterized by an average CEC of $8.6 \mathrm{meq}$ $(100 \mathrm{~g} \text { dry soil })^{-1}$. While the value is comparably low (Batjes, 1997), it can be expected that $\mathrm{Mg}$ is adsorbed onto surfaces of clay minerals and organic matter at the given elevated $\mathrm{pH}$ values.

It is furthermore possible that some parts of the irrigation water bypass the bulk material as preferential flow, possibly along the barrel's rims or potentially through the soil, facilitated by plant roots or evoked by macropores, which lead to the preferential transportation of water downwards, effectively decreasing rock-water interaction times (Nielsen et al., 1986) and therefore dissolution rates in the affected material (Maher, 2011). The process of preferential flow is well established for natural soils (Beven and Germann, 2013), and we assume it asserts some influence on the outflow elemental concentrations in this mesocosm experiment. Future EW experiments using mesocosms or field experiments may therefore include tracking of the effect of preferential flow paths, as it seems from this experiment that hydrology maybe a factor introducing large uncertainty, also considering the seasonality and periods of drying affecting the concentrations and the flux from the system (cf. Fig. 2 with Fig. S12-1).

The amount of $\mathrm{Mg}$ released can theoretically be estimated by multiplying its concentrations with the calculated average outflow water volume at the mesocosm bottom (Fig. S12-1). Yet, due to the observed difference between surface layer and outflow Mg concentrations, it must be assumed that only a small proportion of the initial reaction with the applied grains eventually leads to $\mathrm{CO}_{2}$ sequestration. While this $\mathrm{Mg}$ removal may be specific to the experimental setup, there will be comparable effects in natural environments. To determine the potential order of magnitude of this effect, $\mathrm{Mg}$ concentrations in surface layer pore water and outlet water were compared, and the ratio is near 13 in both setups (Table 3), indicating that the $\mathrm{CO}_{2}$ uptake potential, measured in dissolved $\mathrm{Mg}$, is decreased by more than $90 \%$ compared to the surface layer. The estimated total annual $\mathrm{CO}_{2}$ sequestration at a maximum of $4.9 \mathrm{tCO}_{2} \mathrm{~km}^{-2} \mathrm{a}^{-1}$ is 2 orders of magnitude lower than what was observed in a soil column of $10 \mathrm{~cm}$ diameter and without plants (Renforth et al., 2015). Applied at the global scale, i.e., on all potentially available arable land (minimum and maximum taken from Moosdorf et al., 2014), this yields a comparably low $\mathrm{CO}_{2}$ sequestration potential of maximum $0.07 \mathrm{GtCO}_{2} \mathrm{a}^{-1}$, or less than $0.2 \%$ of the global fossil $\mathrm{CO}_{2}$ emissions of 2017 (based on Le Quéré et al., 2018). When the calculations are based on a $\mathrm{Mg}$ flux neglecting the obvious removal or up-concentration of $\mathrm{Mg}$ due to evapotranspiration, values are about one order of magnitude higher $(\mathrm{Ta}-$ 
ble 3), which makes them comparable to lower-end sequestration rates reported from a smaller pot experiment in ten Berge et al. (2012), which was mainly watered at the bottom to avoid percolation, thus leading to a different environment for elemental cycling.

Also, the globally upscaled estimates do not take geographic variability into account. Since weathering rates are elevated in humid (sub)tropical regions, the global potential based on temperate conditions, and given a comparably low amount of rainfall, is clearly underestimated. Data on $p \mathrm{CO}_{2}$ in the mesocosm soils (Fig. S13-1) corroborate that weathering effects must be less pronounced compared to humid, tropical areas as values in the experiment were 850 $1300 \mu \mathrm{atm}$ in the surface layer $($ depth $=5 \mathrm{~cm})$, whereas they are up to 30 times higher in areas with high evapotranspiration (Brook et al., 1983). Soil water content also seems to be an important control on the soil-rock $p \mathrm{CO}_{2}$ (RomeroMujalli et al., 2018), and therefore seasonality controlling soil water content is likely to be a relevant factor influencing the dissolution kinetics, via the control on soil $p \mathrm{CO}_{2}$, being an important agent in the dissolution process of minerals. Overall, the assessment of global potentials by mesocosm experiments requires setups simulating humid (sub)tropical conditions, which would promote larger fluxes through the soil column.

The large stretch of results shows (a) that cation removal by different chemical and physical processes in soils is an important parameter to include in flux estimates at larger scales, which has not been considered in detail so far, (b) that it is fundamental for such an experiment setup to monitor the water and elemental fluxes through the entire mesocosm, and (c) that the role of seasonal dynamics and amount of the weathering agents like $\mathrm{CO}_{2}$ in the soil should be considered.

\subsection{Trace elements and processes}

The release of trace metals which can be potentially harmful to the environment was mentioned as one of the side effects of terrestrial EW (Hartmann et al., 2013). The effect is especially pronounced when rocks like the dunite in this experiment are applied, since they contain larger amounts of $\mathrm{Cr}$ and $\mathrm{Ni}$ (> $2000 \mathrm{ppm}$ each, Table 1). Nickel (Ni) in olivine is expected to be released as it substitutes for Mg. Chromium (Cr), on the other hand, here present in chromite and chromochlorite from the dunite source rock, is not expected to be released strongly at the observed $\mathrm{pH}$ levels in the system. Soil analysis confirms an increase in these trace metals, due to the added material. The data also show that the lower untreated layers are little affected by the dunite treatment (Fig. 8). Focusing on $\mathrm{Ni}$ and $\mathrm{Cr}$, which are the predominant trace metals in the applied material, soil solution concentrations fluctuate strongly (Fig. 9) due to warmer periods, and subsequent drying-out, causing enrichment of dissolved elements in the solution.
Table 4. Preferential release of $\mathrm{Mg}$ over $\mathrm{Ni}$ into pore water solution during the dissolution of dunite. Molar ratios of $\mathrm{Mg} / \mathrm{Ni}$ in the dunite are based on XRF analysis. Surface layer solution values for fine and coarse setups are averaged over the experimental period.

\begin{tabular}{lrrr}
\hline & \multirow{2}{*}{ Rock } & \multicolumn{2}{c}{ Surface layer solution } \\
\cline { 3 - 4 } & & $\begin{array}{r}\text { Fine setup } \\
\left(\mu \mathrm{mol} \mathrm{kg}^{-1}\right)\end{array}$ & $\begin{array}{r}\text { Coarse setup } \\
\left.(\mu \mathrm{mol} \mathrm{kg})^{-1}\right)\end{array}$ \\
\hline $\mathrm{Mg}$ & 11.2 & 4175 & 638 \\
$\mathrm{Ni}$ & 0.05 & 1.03 & 0.26 \\
$\mathrm{Mg} / \mathrm{Ni}$ molar ratio & 224 & 4053 & 2454 \\
\hline
\end{tabular}

$\mathrm{Ni}$ is partly mobile at the given $\mathrm{pH}$ values. Observed $\mathrm{Ni}$ concentrations exceed drinking water quality thresholds in the surface layer, e.g., formulated by the WHO (2017), with $0.02 \mathrm{mgL}^{-1}\left(\stackrel{\wedge}{=} 339.2 \mathrm{nmolL}^{-1}\right)$, yet are within the recommended limits for agricultural irrigation water $\left(0.2 \mathrm{mgL}^{-1}\right.$; Ayers and Westcot, 1985). This demonstrates that a close water monitoring is necessary to understand implications of a widespread deployment of EW with source materials containing such elevated concentrations of mobile trace metals. Avoiding these particular rock type materials might therefore be the best alternative.

When comparing the theoretical $\mathrm{Mg} / \mathrm{Ni}$ ratio in the olivine with measured data in the soil solution of the surface layer (Table 4), it can be seen that less $\mathrm{Ni}$ is in the solution than theoretically possible (a factor of 10-20 difference, depending on the grain size). Under the given physicochemical conditions it is possible that $\mathrm{Fe}$ and $\mathrm{Al}$ hydroxides lead to the partial sorption of Ni (Young, 2013; Rieuwerts, 2007).

At the same time, Cr is apparently less mobile (Fig. S111) in the mesocosm experiment, considering the sample approach, which matches the general behavior of $\mathrm{Cr}$ mobility at $\mathrm{pH}$ values measured in the soils (at $\mathrm{pH}$ values of $7-$ 9; Kabata-Pendias, 1993). However, elevated $\mathrm{Cr}$ values have been shown for a column experiment, which is to some extent comparable to the mesocosm experiment here. In contrast to our experiment, $\mathrm{Cr}$ values increased more strongly by up to $9 \mathrm{ngg}^{-1}\left(\approx 173 \mathrm{nmol} \mathrm{kg}^{-1}\right)$, including background $\mathrm{Cr}$ (Renforth et al., 2015). Interestingly, $\mathrm{Cr}$ seems to be actively removed from the solution at a later stage of the experiment, shown by $\mathrm{Cr}$ concentrations in the untreated mesocosms being higher than in the treated mesocosms (Fig. 9a), probably due to the higher $\mathrm{pH}$ compared to the control, supporting the idea of $\mathrm{pH}$ management to immobilize $\mathrm{Cr}$.

If trace elements within the applied dunite remain immobile, they accumulate in the soils and can potentially be released when the $\mathrm{pH}$ drops or redox conditions change (McClain and Maher, 2016, and references therein). Grain size effects are visible, shown by elevated concentrations of $\mathrm{Ni}$ in the mesocosms amended with fine olivine. Other trace elements are represented only in smaller amounts in the compo- 
sition of the source rock, thus not releasing relevant amounts into the pore water.

Overall these findings from the mesocosm experiment underline the proposition to focus on alternative sources like basalt (Hartmann et al., 2013; Taylor et al., 2015; Strefler et al., 2018; Amann and Hartmann, 2019) to avoid strong environmental impacts from trace element release.

\section{Conclusion}

Given the scarcity of data considering the field application of rock material for EW, or of compilations of research with other purposes, there are some lessons to be learned from this experiment. The elevated $\mathrm{Mg}$ concentrations indicate the potential of an inorganic $\mathrm{CO}_{2}$ sequestration effect, and the order of magnitude is possibly large enough for the method to be considered to be one piece in the puzzle of negative emission technology (NET) portfolios. However, the calculations are bound to high uncertainties mainly from water flow and elemental concentration estimates throughout the mesocosm. It is crucial to understand processes that can affect the $\mathrm{CO}_{2}$ sequestration potential or impact its assessment, i.e., evapotranspiration, sorption of cations, secondary mineralization, or low overall residence time due to preferential flow of irrigation or rainwater. The concentration difference between the upper soil and the outlet water of about 1 order of magnitude indicates the relevance to include those processes in future experiments to parameterize standardized flux calculations, specifically for environmental conditions with promising $\mathrm{CO}_{2}$ sequestration potential by $\mathrm{EW}$ in areas more humid than represented by the setup of this experiment. This is especially relevant if the $\mathrm{EW} \mathrm{CO}_{2}$ sequestration was to be coupled to a carbon price to regain application costs (Hartmann and Kempe, 2008). Further beneficial services by EW like the potential increase in plant biomass via uptake of growthlimiting elements provided by rocks, or the increase in secondary minerals positively affecting nutrient retention, were not investigated here but are an essential part of future studies to assess the full potential of EW as a method for carbon dioxide removal (Amann and Hartmann, 2019), and potentially for $\mathrm{pH}$ management, avoiding the release of further greenhouse gases like $\mathrm{N}_{2} \mathrm{O}$ (Kantola et al., 2017).

One of the main concerns of the rock powder application is the release of potentially harmful trace elements. It could be shown for the first time in a dedicated EW experiment in an open system with plants that levels of $\mathrm{Ni}$ in solution are significantly elevated, whereas it was possible to confirm that Cr levels in solution are low under the given soil conditions.

The experiment also showed that the behavior of silica in the soil is not well understood if silicate powder of different grain sizes is applied. This is evidenced by the high $\mathrm{Mg} / \mathrm{Si}$ ratios and the potential sink of silica in comparison to the non-silicate-treated mesocosms. Results appear to be consistent with published observations that the formation of a cation-depleted and Si-enriched grain surface layer is responsible for the missing silica. The available data do not allow further conclusions here. Nonetheless, the effect of a growing depleted silica layer on the dissolution kinetics and of further secondary mineral phases should be investigated, specifically if a long-term application of EW is envisaged. Using more complex rock products, like basalt with higher aluminum content, may produce larger amounts of new phyllosilicates and other products around the added fresh mineral grains, changing their kinetic behavior in the long term.

Overall, this shows that mesoscale and field experiments are of the utmost importance to identify the essential processes, to decrease uncertainties in process understanding and element releases, and to address the effects of elevated element fluxes. Only if budgets of EW can be estimated reliably, could the resulting $\mathrm{CO}_{2}$ consumption be bound to a carbon prize within a NET deployment strategy.

Data availability. The data used in this experiment are provided as comma-separated files in the Supplement.

Supplement. The supplement related to this article is available online at: https://doi.org/10.5194/bg-17-103-2020-supplement.

Author contributions. This article was conceived through the joint work of ES, JS, JH, and TA, who all participated in discussions, planning, and writing, with the lead of TA. The mesocosm study was conceived and designed by ES, JS, PM, and IJ. Sampling was primarily conducted by ES and JS. Mg and Si analyses were performed by ES and JS, trace elements were analyzed by EKF, and DIC was measured by TA. WdOG contributed to the discussion of trace elements. JH contributed to the discussion of weathering effects.

Competing interests. The authors declare that they have no conflict of interest.

Acknowledgements. This research was executed with the financial support of the Research Foundation Flanders (FWO), project no. G043313N "Silicate fertilization, crop production and carbon storage: a new and integrated concept for sustainable management of agricultural ecosystems". Jonas Schoelynck is a postdoctoral fellow of FWO (project no. 12H8616N). Additional support was provided by the German Research Foundation's priority program DFG SPP 1689 on "Climate Engineering - Risks, Challenges and Opportunities?" and specifically the CEMICS2 project to Thorben Amann, Jens Hartmann, and Wagner de Oliveira Garcia. Further support of Thorben Amann and Jens Hartmann came from the Deutsche Forschungsgemeinschaft (DFG, German Research Foundation) under Germany's Excellence Strategy - EXC 2037 "Climate, Climatic Change, and Society" - project number 390683824 , contribution to the Center for Earth System Research and Sustain- 
ability (CEN) of Universität Hamburg, and through the previous EXC177 “CLISAP2", Universität Hamburg.

We acknowledge Peggy Bartsch, Tom Jäppinen, Marvin Keitzel, and Andreas Weiss for valuable contributions from the wet lab and Sebastian Lindhorst for providing granulometric analyses (all from the Institute for Geology, Universität Hamburg). We thank Stephan Jung and Joachim Ludwig (from the Institute for Mineralogy and Petrography, Universität Hamburg) for contributing the XRF and XRD analyses. All employees of the Antwerp city greenhouse are thanked for their practical support.

We thank the editor and reviewers for their insightful comments on our paper. We would specifically like to acknowledge Søren Jessen for his thorough reviews.

Financial support. This research has been supported by the Research Foundation Flanders (grant nos. G043313N and 12H8616N) and the German Research Foundation (grant nos. SPP1689, EXC177, and EXC 2037).

Review statement. This paper was edited by Andreas Ibrom and reviewed by Søren Jessen and David Manning.

\section{References}

Amann, T. and Hartmann, J.: Ideas and perspectives: Synergies from co-deployment of negative emission technologies, Biogeosciences, 16, 2949-2960, https://doi.org/10.5194/bg-16-29492019, 2019.

Anda, M., Shamshuddin, J., and Fauziah, C. I.: Increasing negative charge and nutrient contents of a highly weathered soil using basalt and rice husk to promote cocoa growth under field conditions, Soil Till. Res., 132, 1-11, https://doi.org/10.1016/j.still.2013.04.005, 2013.

Anda, M., Shamshuddin, J., and Fauziah, C. I.: Improving chemical properties of a highly weathered soil using finely ground basalt rocks, CATENA, 124, 147-161, https://doi.org/10.1016/j.catena.2014.09.012, 2015a.

Anda, M., Suryani, E., and Husnain, D. S.: Strategy to reduce fertilizer application in volcanic paddy soils: Nutrient reserves approach from parent materials, Soil Till. Res., 150, 10-20, https://doi.org/10.1016/j.still.2015.01.005, 2015b.

Ayers, R. S. and Westcot, D. W.: Water quality for agriculture, Food and Agriculture Organization of the United Nations, Rome, 1985.

Batjes, N. H.: A world dataset of derived soil properties by FAOUNESCO soil unit for global modelling, Soil Use Manage., 13, 9-16, https://doi.org/10.1111/j.1475-2743.1997.tb00550.x, 1997.

Beerling, D. J.: Enhanced rock weathering: biological climate change mitigation with co-benefits for food security?, Biol. Lett., 13, 20170149, https://doi.org/10.1098/rsbl.2017.0149, 2017.

Beerling, D. J., Leake, J. R., Long, S. P., Scholes, J. D., Ton, J., Nelson, P. N., Bird, M., Kantzas, E., Taylor, L. L., Sarkar, B., Kelland, M., DeLucia, E., Kantola, I., Muller, C., Rau, G., and Hansen, J.: Farming with crops and rocks to address global climate, food and soil security, Nat. Plants, 4, 138-147, https://doi.org/10.1038/s41477-018-0108-y, 2018.

Berner, R. A.: The long-term carbon cycle, fossil fuels and atmospheric composition, Nature, 426, 323-326, https://doi.org/10.1038/nature02131, 2003.

Beven, K. and Germann, P.: Macropores and water flow in soils revisited, Water Resour. Res., 49, 3071-3092, https://doi.org/10.1002/wrcr.20156, 2013.

Beyer, E. E.: Transformation of Archaean Lithospheric Mantle by Refertilization: Evidence from Exposed Peridotites in the Western Gneiss Region, Norway, J. Petrol., 47, 1611-1636, https://doi.org/10.1093/petrology/eg1022, 2006.

Brook, G. A., Folkoff, M. E., and Box, E. O.: A World Model Of Soil Carbon Dioxide, Earth Surf. Proc. Land., 8, 79-88, https://doi.org/10.1002/esp.3290080108, 1983.

Brunauer, S., Emmett, P. H., and Teller, E.: Adsorption of Gases in Multimolecular Layers, J. Am. Chem. Soc., 60, 309-319, https://doi.org/10.1021/ja01269a023, 1938.

Case, D. H., Wang, F., and Giammar, D. E.: Precipitation of Magnesium Carbonates as a Function of Temperature, Solution Composition, and Presence of a Silicate Mineral Substrate, Environ. Eng. Sci., 28, 881-889, https://doi.org/10.1089/ees.2010.0341, 2011.

Casey, W. H., Westrich, H. R., Banfield, J. F., Ferruzzi, G., and Arnold, G. W.: Leaching and Reconstruction at the Surfaces of Dissolving Chain-Silicate Minerals, Nature, 366, 253-256, https://doi.org/10.1038/366253a0, 1993.

Ciceri, D. and Allanore, A.: Local fertilizers to achieve food self-sufficiency in Africa, Sci. Total Environ., 648, 669-680, https://doi.org/10.1016/j.scitotenv.2018.08.154, 2019.

Cordell, D., Drangert, J.-O., and White, S.: The story of phosphorus: Global food security and food for thought, Global Environ. Change, 19, 292-305, https://doi.org/10.1016/j.gloenvcha.2008.10.009, 2009.

Cregan, P., Hirth, J., and Conyers, M.: Amelioration of Siol Acidity by Liming and other Amendments, in: Soil Acidity and Plant Growth, edited by: Robson, A., Academic Press Australia, Marrickville, 1989.

Daval, D., Sissmann, O., Menguy, N., Saldi, G. D., Guyot, F., Martinez, I., Corvisier, J., Garcia, B., Machouk, I., Knauss, K. G., and Hellmann, R.: Influence of amorphous silica layer formation on the dissolution rate of olivine at $90^{\circ} \mathrm{C}$ and elevated $p \mathrm{CO}_{2}$, Chem. Geol., 284, 193-209, https://doi.org/10.1016/j.chemgeo.2011.02.021, 2011.

Daval, D., Hellmann, R., Martinez, I., Gangloff, S., and Guyot, F.: Lizardite serpentine dissolution kinetics as a function of $\mathrm{pH}$ and temperature, including effects of elevated $p \mathrm{CO}_{2}$, Chem. Geol., 351, 245-256, https://doi.org/10.1016/j.chemgeo.2013.05.020, 2013a.

Daval, D., Hellmann, R., Saldi, G. D., Wirth, R., and Knauss, K. G.: Linking nm-scale measurements of the anisotropy of silicate surface reactivity to macroscopic dissolution rate laws: New insights based on diopside, Geochim. Cosmochim. Ac., 107, 121134, https://doi.org/10.1016/j.gca.2012.12.045, 2013 b.

de Oliveira Garcia, W., Amann, T., and Hartmann, J.: Increasing biomass demand enlarges negative forest nutrient budget areas in wood export regions, Sci. Rep.-UK, 8, 5280, https://doi.org/10.1038/s41598-018-22728-5, 2018. 
De Villiers, O. D. H.: Soil rejuvenation with crushed basalt in Mauritius, Int. Sugar J., 63, 363-364, 1961.

Edwards, D. P., Lim, F., James, R. H., Pearce, C. R., Scholes, J., Freckleton, R. P., and Beerling, D. J.: Climate change mitigation: potential benefits and pitfalls of enhanced rock weathering in tropical agriculture, Biol. Lett., 13, 20160715, https://doi.org/10.1098/rsbl.2016.0715, 2017.

Fuss, S., Canadell, J. G., Peters, G. P., Tavoni, M., Andrew, R. M., Ciais, P., Jackson, R. B., Jones, C. D., Kraxner, F., Nakicenovic, N., Le Quere, C., Raupach, M. R., Sharifi, A., Smith, P., and Yamagata, Y.: Betting on negative emissions, Nat. Clim. Change, 4, 850-853, https://doi.org/10.1038/nclimate2392, 2014.

Fuss, S., Lamb, W. F., Callaghan, M. W., Hilaire, J., Creutzig, F., Amann, T., Beringer, T., de Oliveira Garcia, W., Hartmann, J., Khanna, T., Luderer, G., Nemet, G. F., Rogelj, J., Smith, P., Vicente, J. L. V., Wilcox, J., del Mar Zamora Dominguez, M., and Minx, J. C.: Negative emissions - Part 2: Costs, potentials and side effects, Environ. Res. Lett., 13, 063002, https://doi.org/10.1088/1748-9326/aabf9f, 2018.

Giammar, D. E., Bruant, R. G., and Peters, C. A.: Forsterite dissolution and magnesite precipitation at conditions relevant for deep saline aquifer storage and sequestration of carbon dioxide, Chem. Geol., 217, 257-276, https://doi.org/10.1016/j.chemgeo.2004.12.013, 2005.

Hartmann, J. and Kempe, S.: What is the maximum potential for $\mathrm{CO}_{2}$ sequestration by "stimulated" weathering on the global scale?, Naturwissenschaften, 95, 1159-1164, https://doi.org/10.1007/s00114-008-0434-4, 2008.

Hartmann, J., Jansen, N., Kempe, S., and Dürr, H.: Geochemistry of the river Rhine and the upper Danube: Recent trends and lithological influence on baselines, Journal of Environmental Science for Sustainable Society, 1, 39-46, https://doi.org/10.3107/jesss.1.39, 2007.

Hartmann, J., Levy, J., and Kempe, S.: Increasing dissolved silica trends in the Rhine River: an effect of recovery from high P loads?, Limnology, 12, 63-73, https://doi.org/10.1007/s10201010-0322-4, 2011.

Hartmann, J., West, A. J., Renforth, P., Köhler, P., De La Rocha, C. L., Wolf-Gladrow, D. A., Dürr, H. H., and Scheffran, J.: Enhanced chemical weathering as a geoengineering strategy to reduce atmospheric carbon dioxide, supply nutrients, and mitigate ocean acidification, Rev. Geophys., 51, 113-149, https://doi.org/10.1002/rog.20004, 2013.

Haynes, R. J. and Naidu, R.: Influence of lime, fertilizer and manure applications on soil organic matter content and soil physical conditions: a review, Nutr. Cycl. Agroecosys., 51, 123-137, https://doi.org/10.1023/A:1009738307837, 1998.

Heinrichs, H. and Herrmann, A. G.: Praktikum der analytischen Geochemie, Springer-Verlag, Berlin Heidelberg, 2013.

Hellmann, R., Wirth, R., Daval, D., Barnes, J.-P., Penisson, J.-M., Tisserand, D., Epicier, T., Florin, B., and Hervig, R. L.: Unifying natural and laboratory chemical weathering with interfacial dissolution-reprecipitation: A study based on the nanometerscale chemistry of fluid-silicate interfaces, Chem. Geol., 294295, 203-216, https://doi.org/10.1016/j.chemgeo.2011.12.002, 2012.

Hövelmann, J., Austrheim, H., and Jamtveit, B.: Microstructure and porosity evolution during experimental carbona- tion of a natural peridotite, Chem. Geol., 334, 254-265, https://doi.org/10.1016/j.chemgeo.2012.10.025, 2012.

Iler, R. K.: The Chemistry of Silica. Solubility, Polymerization, Colloid and Surface Properties, and Biochemistry, John Wiley \& Sons, New York/Chichester/Brisbane/Toronto, 866 pp., 1979.

IPCC: Climate Change and Land: an IPCC special report on climate change, desertification, land degradation, sustainable land management, food security, and greenhouse gas fluxes in terrestrial ecosystems, edited by: Shukla, P. R., Skea, J., Calvo Buendia, E., Masson-Delmotte, V., Pörtner, H.-O., Roberts, D. C., Zhai, P., Slade, R., Connors, S., van Diemen, R., Ferrat, M., Haughey, E., Luz, S., Neogi, S., Pathak, M., Petzold, J., Portugal Pereira, J., Vyas, P., Huntley, E., Kissick, K., Belkacemi, M., and Malley, J., In press, 2019.

Kabata-Pendias, A.: Behavioral Properties of Trace-Metals in Soils, Appl. Geochem., Supplementary Issue No 2, January 1993, 3-9, https://doi.org/10.1016/S0883-2927(09)80002-4, 1993.

Kantola, I. B., Masters, M. D., Beerling, D. J., Long, S. P., and DeLucia, E. H.: Potential of global croplands and bioenergy crops for climate change mitigation through deployment for enhanced weathering, Biol. Lett., 13, 20160714, https://doi.org/10.1098/rsbl.2016.0714, 2017.

Köhler, P., Hartmann, J., and Wolf-Gladrow, D. A.: Geoengineering potential of artificially enhanced silicate weathering of olivine, P. Natl. Acad. Sci. USA, 107, 20228-20233, https://doi.org/10.1073/pnas.1000545107, 2010.

Kronberg, B. I.: The geochemistry of some Brazilian soils and geochemical considerations for agriculture on highly leached soils, $\mathrm{PhD}$, The University of Western Ontario, Ontario, 1977.

Leonardos, O. H., Fyfe, W. S., and Kronberg, B. I.: The use of ground rocks in laterite systems: An improvement to the use of conventional soluble fertilizers?, Chem. Geol., 60, 361-370, https://doi.org/10.1016/0009-2541(87)90143-4, 1987.

Le Quéré, C., Andrew, R. M., Friedlingstein, P., Sitch, S., Hauck, J., Pongratz, J., Pickers, P. A., Korsbakken, J. I., Peters, G. P., Canadell, J. G., Arneth, A., Arora, V. K., Barbero, L., Bastos, A., Bopp, L., Chevallier, F., Chini, L. P., Ciais, P., Doney, S. C., Gkritzalis, T., Goll, D. S., Harris, I., Haverd, V., Hoffman, F. M., Hoppema, M., Houghton, R. A., Hurtt, G., Ilyina, T., Jain, A. K., Johannessen, T., Jones, C. D., Kato, E., Keeling, R. F., Goldewijk, K. K., Landschützer, P., Lefèvre, N., Lienert, S., Liu, Z., Lombardozzi, D., Metzl, N., Munro, D. R., Nabel, J. E. M. S., Nakaoka, S., Neill, C., Olsen, A., Ono, T., Patra, P., Peregon, A., Peters, W., Peylin, P., Pfeil, B., Pierrot, D., Poulter, B., Rehder, G., Resplandy, L., Robertson, E., Rocher, M., Rödenbeck, C., Schuster, U., Schwinger, J., Séférian, R., Skjelvan, I., Steinhoff, T., Sutton, A., Tans, P. P., Tian, H., Tilbrook, B., Tubiello, F. N., van der Laan-Luijkx, I. T., van der Werf, G. R., Viovy, N., Walker, A. P., Wiltshire, A. J., Wright, R., Zaehle, S., and Zheng, B.: Global Carbon Budget 2018, Earth Syst. Sci. Data, 10, 2141 2194, https://doi.org/10.5194/essd-10-2141-2018, 2018.

Maher, K.: The role of fluid residence time and topographic scales in determining chemical fluxes from landscapes, Earth Planet Sc. Lett., 312, 48-58, https://doi.org/10.1016/j.epsl.2011.09.040, 2011.

Maher, K., Johnson, N. C., Jackson, A., Lammers, L. N., Torchinsky, A. B., Weaver, K. L., Bird, D. K., and Brown, G. E.: A spatially resolved surface kinetic model for 
forsterite dissolution, Geochim. Cosmochim. Ac., 174, 313-334, https://doi.org/10.1016/j.gca.2015.11.019, 2016.

Manning, D. A. C.: How will minerals feed the world in 2050?, Proceedings of the Geologists' Association, 126, 14-17, https://doi.org/10.1016/j.pgeola.2014.12.005, 2015.

McClain, C. N. and Maher, K.: Chromium fluxes and speciation in ultramafic catchments and global rivers, Chem. Geol., 426, 135157, https://doi.org/10.1016/j.chemgeo.2016.01.021, 2016.

Meybeck, M.: Global analysis of river systems: from Earth system controls to Anthropocene syndromes, Philos. T. R. Soc. Lon. B, 358, 1935-1955, https://doi.org/10.1098/rstb.2003.1379, 2003.

Minx, J. C., Lamb, W. F., Callaghan, M. W., Fuss, S., Hilaire, J., Creutzig, F., Amann, T., Beringer, T., de Oliveira Garcia, W., Hartmann, J., Khanna, T., Lenzi, D., Luderer, G., Nemet, G. F., Rogelj, J., Smith, P., Vicente Vicente, J. L., Wilcox, J., and del Mar Zamora Dominguez, M.: Negative emissions - Part 1: Research landscape and synthesis, Environ. Res. Lett., 13, 063001, https://doi.org/10.1088/1748-9326/aabf9b, 2018.

Montserrat, F., Renforth, P., Hartmann, J., Leermakers, M., Knops, P., and Meysman, F. J. R.: Olivine dissolution in seawater: implications for $\mathrm{CO}_{2}$ sequestration through Enhanced Weathering in coastal environments, Environ. Sci. Technol., 51, 3960-3972, https://doi.org/10.1021/acs.est.6b05942, 2017.

Moosdorf, N., Renforth, P., and Hartmann, J.: Carbon dioxide efficiency of terrestrial enhanced weathering, Environ. Sci. Technol., 48, 4809-4816, https://doi.org/10.1021/es4052022, 2014.

Naderi, M.: Chapter Fourteen - Surface Area: Brunauer-EmmettTeller (BET), in: Progress in Filtration and Separation, edited by: Tarleton, S., Academic Press, Oxford, 585-608, 2015.

Nielsen, D. R., Van Genuchten, Th., M., and Biggar, J. W.: Water flow and solute transport processes in the unsaturated zone, Water Resour. Res., 22, 89S-108S, https://doi.org/10.1029/WR022i09Sp0089S, 1986.

Nugent, M. A., Brantley, S. L., Pantano, C. G., and Maurice, P. A.: The influence of natural mineral coatings on feldspar weathering, Nature, 395, 588-591, https://doi.org/10.1038/26951, 1998.

Peters, G. P.: The "best available science" to inform $1.5^{\circ} \mathrm{C}$ policy choices, Nat. Clim. Change, 6, 646-649, https://doi.org/10.1038/nclimate3000, 2016.

Pokrovsky, O. S. and Schott, J.: Kinetics and mechanism of forsterite dissolution at $25^{\circ} \mathrm{C}$ and $\mathrm{pH}$ from 1 to 12 , Geochim. Cosmochim. Ac., 64, 3313-3325, https://doi.org/10.1016/s00167037(00)00434-8, 2000.

Prudêncio, M. I., Sequeira Braga, M. A., Paquet, H., Waerenborgh, J. C., Pereira, L. C. J., and Gouveia, M. A.: Clay mineral assemblages in weathered basalt profiles from central and southern Portugal: climatic significance, CATENA, 49, 77-89, https://doi.org/10.1016/S0341-8162(02)00018-8, 2002.

Radach, G. and Pätsch, J.: Variability of continental riverine freshwater and nutrient inputs into the North Sea for the years 19772000 and its consequences for the assessment of eutrophication, Estuar. Coasts, 30, 66-81, https://doi.org/10.1007/Bf02782968, 2007.

Raymond, P. A. and Cole, J. J.: Increase in the export of alkalinity from North America's largest river, Science, 301, 88-91, https://doi.org/10.1126/science.1083788, 2003.

Raymond, P. A. and Hamilton, S. K.: Anthropogenic influences on riverine fluxes of dissolved inorganic car- bon to the oceans, Limnol. Oceanogr. Lett., 3, 143-155, https://doi.org/10.1002/lol2.10069, 2018.

Renforth, P.: The potential of enhanced weathering in the UK, Int. J. Greenh. Gas Con., 10, 229-243, https://doi.org/10.1016/j.ijggc.2012.06.011, 2012.

Renforth, P., Jenkins, B. G., and Kruger, T.: Engineering challenges of ocean liming, Energy, 60, 442-452, https://doi.org/10.1016/j.energy.2013.08.006, 2013.

Renforth, P., Pogge von Strandmann, P. A. E., and Henderson, G. M.: The dissolution of olivine added to soil: Implications for enhanced weathering, Appl. Geochem., 61, 109-118, https://doi.org/10.1016/j.apgeochem.2015.05.016, 2015.

Rieuwerts, J. S.: The mobility and bioavailability of trace metals in tropical soils: a review, Chem. Spec. Bioavailab., 19, 75-85, https://doi.org/10.3184/095422907X211918, 2007.

Rogelj, J., Popp, A., Calvin, K. V., Luderer, G., Emmerling, J., Gernaat, D., Fujimori, S., Strefler, J., Hasegawa, T., Marangoni, G., Krey, V., Kriegler, E., Riahi, K., van Vuuren, D. P., Doelman, J., Drouet, L., Edmonds, J., Fricko, O., Harmsen, M., Havlík, P., Humpenöder, F., Stehfest, E., and Tavoni, M.: Scenarios towards limiting global mean temperature increase below $1.5^{\circ} \mathrm{C}$, Nat. Clim. Change, 8, 325-332, https://doi.org/10.1038/s41558018-0091-3, 2018.

Romero-Mujalli, G., Hartmann, J., Börker, J., Gaillardet, J., and Calmels, D.: Ecosystem controlled soil-rock pCO2 and carbonate weathering - Constraints by temperature and soil water content, Chem. Geol., 527, 118634, https://doi.org/10.1016/j.chemgeo.2018.01.030, 2018.

Rosso, J. J. and Rimstidt, J. D.: A high resolution study of forsterite dissolution rates, Geochim. Cosmochim. Ac., 64, 797811, https://doi.org/10.1016/S0016-7037(99)00354-3, 2000.

Ruiz-Agudo, E., Putnis, C. V., Rodriguez-Navarro, C., and Putnis, A.: Mechanism of leached layer formation during chemical weathering of silicate minerals, Geology, 40, 947-950, https://doi.org/10.1130/g33339.1, 2012.

Sanderson, B. M., O'Neill, B. C., and Tebaldi, C.: What would it take to achieve the Paris temperature targets?, Geophys. Res. Lett., 43, 7133-7142, https://doi.org/10.1002/2016g1069563, 2016.

Schuiling, R. D. and Krijgsman, P.: Enhanced weathering: An effective and cheap tool to sequester $\mathrm{CO}_{2}$, Clim. Change, 74, 349354, https://doi.org/10.1007/s10584-005-3485-y, 2006.

Shamshuddin, J. and Anda, M.: Enhancing the Productivity of Ultisols and Oxisols in Malaysia using Basalt and/or Compost, Pedologist, 2012, 382-391, https://doi.org/10.18920/pedologist.55.3_382, 2012.

Shamshuddin, J., Anda, M., Fauziah, C. I., and Omar, S. R. S.: Growth of Cocoa Planted on Highly Weathered Soil as Affected by Application of Basalt and/or Compost, Commun. Soil Sci. Plan., 42, 2751-2766, https://doi.org/10.1080/00103624.2011.622822, 2011.

Smith, L. K.: Weathering of basalt: formation of iddingsite, Clay. Clay Miner., 35, 418-428, https://doi.org/10.1346/Ccmn.1987.0350602, 1987.

Strefler, J., Amann, T., Bauer, N., Kriegler, E., and Hartmann, J.: Potential and costs of carbon dioxide removal by enhanced weathering of rocks, Environ. Res. Lett., 13, 034010 , https://doi.org/10.1088/1748-9326/aaa9c4, 2018. 
Stumm, W. and Morgan, J. J.: Aquatic Chemistry: Chemical Equilibria and Rates in Natural Waters, 3rd edn., in: Environmental Science and Technology, edited by: Schnoor, J. L. and Zehnder, A., John Wiley \& Sons, Inc., New York, 1996.

Taylor, L. L., Quirk, J., Thorley, R. M. S., Kharecha, P. A., Hansen, J., Ridgwell, A., Lomas, M. R., Banwart, S. A., and Beerling, D. J.: Enhanced weathering strategies for stabilizing climate and averting ocean acidification, Nat. Clim. Change, 6, 402-406, https://doi.org/10.1038/nclimate2882, 2015.

Taylor, L. L., Beerling, D. J., Quegan, S., and Banwart, S. A.: Simulating carbon capture by enhanced weathering with croplands: an overview of key processes highlighting areas of future model development, Biol. Lett., 13, 20160868, https://doi.org/10.1098/rsbl.2016.0868, 2017.

ten Berge, H. F. M., van der Meer, H. G., Steenhuizen, J. W., Goedhart, P. W., Knops, P., and Verhagen, J.: Olivine Weathering in Soil, and Its Effects on Growth and Nutrient Uptake in Ryegrass Lolium perenne L.: A Pot Experiment, PLoS ONE, 7, e42098, https://doi.org/10.1371/journal.pone.0042098, 2012.

Thaysen, E. M., Jacques, D., Jessen, S., Andersen, C. E., Laloy, E., Ambus, P., Postma, D., and Jakobsen, I.: Inorganic carbon fluxes across the vadose zone of planted and unplanted soil mesocosms, Biogeosciences, 11, 7179-7192, https://doi.org/10.5194/bg-117179-2014, 2014. van Straaten, P.: Rocks for Crops: Agrominerals of sub-Saharan Africa, ICRAF, Nairobi, Kenya, 338 pp., 2002.

van Straaten, P.: Farming with rocks and minerals: challenges and opportunities, Anais da Academia Brasileira de Ciencias, 78, 731-747, https://doi.org/10.1590/S0001-37652006000400009, 2006.

WHO: Guidelines for drinking-water quality, fourth edition incorporating the first addendum, World Health Organization, Geneva, 2017.

Wogelius, R. A. and Walther, J. V.: Olivine Dissolution Kinetics at near-Surface Conditions, Chem. Geol., 97, 101-112, https://doi.org/10.1016/0009-2541(92)90138-U, 1992.

Young, S. D.: Chemistry of Heavy Metals and Metalloids in Soils, in: Heavy Metals in Soils: Trace Metals and Metalloids in Soils and their Bioavailability, edited by: Alloway, B. J., Springer Netherlands, Dordrecht, 51-95, 2013. 